Rafał Gawałkiewicz

ORCID: 0000-0003-4261-1697

\title{
SULPHUR MINE “PIASECZNO” - vol. 1. HISTORICAL QUERY OF 1958-2012, GEOLOGY AND HYDROLOGY OF THE MINE REGION, RECLAMATION
}

\author{
AGH University of Science and Technology, Faculty of Mining Surveying and Environmental Engineering, Krakow, Poland
}

Keywords: Sulphur Mine "Piaseczno", reclamation of post-mining excavations

\begin{abstract}
Two post-mining excavations (relics of sulphur mining), nowadays filled with water are characteristic elements of the landscape in the Tarnobrzeg Region. They became historic and permanent trace of open-cast mining in Piaseczno (left bank of the Vistula River) in 1958-1971 and Machów (right bank of the Vistula River) in 1970-1992. The process of the reclamation of the excavation in Machów ended successfully and the water body became a popular place of leisure and recreation for the residents of the town and the vicinity. Unfortunately, in case of the excavation in Piaseczno, despite many years of liquidation and reclamation works, regaining utility values and ecological values in these areas has not been accomplished yet. There is still real risk of mass land movements of watered ground in the area above the water table, which limits the possibility of adapting the water body for any other purposes than retention and ecological reclamation. Despite short 13-years' history of mining sulphur and nearly 10 years of mining the Baranów sands, the Sulphur Mine "Piaseczno" has interesting history, due to the mining activities (stages: exploitation, liquidation and reclamation) and the forces of nature, which make a serious problem in the process of completing the works to bring back the utilitarian values of the areas of already non-existing mining area.

Based on the analysis and post-processing of the available archival cartographic materials while using information tool (Surfer, AutoCAD), it was possible to make detail parameters of the water body Piaseczno and prove the impact of reclamation works and natural phenomena (mass movements) on the shape of the lake bowl and water scarps of the excavation.
\end{abstract}

\section{KOPALNIA SIARKI „PIASECZNO” - cz. 1. KWERENDA HISTORYCZNA WYROBISKA OKRESU 1958-2012, GEOLOGIA I HYDROLOGIA REJONU KOPALNI, REKULTYWACJA}

Słowa kluczowe: Kopalnia Siarki „Piaseczno”, rekultywacja wyrobisk pogórniczych

\begin{abstract}
Abstrakt
Charakterystycznymi elementami krajobrazu rejonu tarnobrzeskiego są dwa poeksploatacyjne wyrobiska (relikty górnictwa siarkowego), obecnie wypełnione wodą. Stanowią historyczny i trwały ślad odkrywkowej działalności górniczej prowadzonej w Piasecznie (lewobrzeżna Wisła) w latach 1958-1971 oraz w Machowie (prawobrzeżna Wisła) w latach 1970-1992. Proces rekultywacji wyrobiska Machów zakończono pomyślnie i od kliku lat zbiornik wodny stanowi popularne miejsce wypoczynku i rekreacji mieszkańców miasta i okolic. Niestety w przypadku wyrobiska Piaseczno, mimo wielu lat prac likwidacyjnych i rekultywacyjnych, przywracanie wartości użytkowych i przyrodniczych tym terenom nie zostało zakończone. Nadal istnieje realne ryzyko masowych ruchów zawodnionych warstw ziemi w strefie nadwodnej, co ogranicza możliwość adaptacji zbiornika na cele inne niż tylko retencja i użytek przyrodniczy. Mimo krótkiej trzynastoletniej historii wydobycia
\end{abstract}


rud siarki oraz blisko dziesięcioletniej eksploatacji piasków baranowskich (szklarskich) Kopalnia Siarki „Piaseczno” ma ciekawą historię, za sprawą działalności górniczej (etapy: eksploatacji, likwidacji i rekultywacji) oraz sił natury, które stanowią poważny problem w procesie zakończenia prac zmierzających do przywrócenia wartości użytkowej terenom nieistniejącego już obszaru górniczego.

Na podstawie analizy i post-processingu dostępnych archiwalnych materiałów kartograficznych przy wykorzystaniu narzędzi informatycznych (Surfer, AutoCAD), możliwe było szczegółowe sparametryzowanie zbiornika Piaseczno oraz wykazanie wpływu prac rekultywacyjnych oraz zjawisk naturalnych (ruchów masowych) na kształt misy jeziornej oraz skarp nadwodnych wyrobiska.

\section{INTRODUCTION}

The year 1415 marks the beginning of sulphur mining in Poland. First exploration works were connected with sulphur deposit were carried out in Swoszowice (Krakow) based on the privilege law by King Władysław Jagiełło. The founders of the mining brotherhood were the burghers of Krakow: Michał Fayger, Piotr Słodownik, Mikołaj Sołtys and miner Krystian (Kubica B., Osmólski T., 1964). Despite small depth of the deposit $(20-30 \mathrm{~m})$ the mining, till the end of $19^{\text {th }}$ century, was underground (deposit was taken out through shafts, similarly to salt mining). During the partitions the mine covered $80-90 \%$ needs for sulphur in the Austro-Hungarian Empire. Other historical centres of sulphur mining in Poland were the mines in: Posądza (Krakow), Czarkowy (activities carried out for the needs of Tsarist Russia), Czajkowo (Kielce), Pszów and Kokoszyce (Silesia), Dźwiniacz, Truskawiec and Lubień (Opole). Among the mentioned above, the latest closed mine was in Posądza - in 1921 (the shortest time of mine working -6 years). During the carried out by the Polish People's Republic 6-years' Plan, the deposits of sulphur in the mentioned above mines were regarded out-of-balance not corresponding by the contemporary needs of the country (Pawłowski S., 1983).

The development of sulphur mining as early as in $15^{\text {th }}$ century resulted from the need for this mineral in alchemy and medicine. Sulphur mixed with saltpetre and charcoal made gunpowder, applied for black powder guns was commonly used till the end of $19^{\text {th }}$ century. Moreover, it has been commonly used up till now in many industries: tanning (leather industry), textile (making rayon, bleaching cotton and linen), match industry, metallurgy (digestion of metals), chemical industry (production of: dyes, sulphuric acid and carbon disulphide) and petrochemical industry (the process of oil refining), paint industry, paper industry, fertilizers, weapon (making explosives).
The discovery of the deposits of elemental sulphur in 1953 (according to Pawłowski S., 1983 - the beginning of the new era of the exploration of sulphur deposit and their exploitation in the region of Tarnobrzeg in 1950s) caused dynamic development of chemical industry within the borders of the Kielce voivodeship of those times. The development of the machine infrastructure caused that the open cast mining in Piaseczno was economically justified. The open cast mining of the deposit (classical method of mining sulphur, lignite, gypsum and other chemical deposits as well as aggregates), was one of the commonest in the world ways of getting shallow solid deposits. The choice of this method in the region of Tarnobrzeg resulted from geological structure and small depth of the deposit not exceeding 100 m (Kwiecień K., 1978).

Unfortunately, such a way of exploitation makes the investors buy land from the owners of real estate where mining is planned. This refers not only to land directly designed for mining, i.e., exploration and exploitation of deposit, but also land used to dispose the overburden (spoil tips), technological sites, transport and servicing facilities, social facilities and offices, etc. Such an area is subdued to long-lasting industrial degradation and the ending of mining resulting from the liquidation of the mine (exhausting of the deposit or lack of profitability) has been making mining enterprises carry out reclamation to bring the degraded land back to its utility and ecological values (Goszcz A., 2001) by proper shaping the relief, improving physical and chemical properties of water, regulating water balance, restoration of soil, stabilization of the scarps of the excavation and repository, reconstruction of road infrastructure (Szczepiński 2018). This directly results from art. 128, pt. 4 of the Geological and Mining Law (Prawo geologiczne i górnicze) (Dz.U. of 2020, position 1064), which makes the investor planning open-cast mining secure funds for the future liquidation of mine and the amount of the money must not be lower than $10 \%$ of the mining fee 
after the end of each fiscal year. This obligation ends on the day of the beginning of the mine liquidation. At the mining in Piaseczno ended,9 there were no regulations demanding special funds for liquidation, thus reclamation process was financed by the National Fund of Environmental Protection and Water Management (Narodowy Fundusz Ochrony Środowiska i Gospodarki Wodnej-NFOŚiGW). The substancial and financial supervision (accepting the liquidation projects, analysis of reports referring to the stages of the liquidation of the mine, monthly reports on expenditures of the subsidies) is within the responsibility of the Minister of Economy, according to art. 7 point 1 of the Law on Financial Restructuring of Sulphur Mining of 14 July 2000 (Dz. U. of 2003, No. 175, position 1693).

The process of returning the post-mining terrains specific functions and their reasonable management make a serious technical and economic challenge. This is a very complicated process, requiring the integration of actions carried out by many specialists in mining, geo-engineering and geo-technology, geology, civil engineering, surveying, as well as ecology. Only interdisciplinary character of these activities allows bringing these areas utility functions (understood as protection of arable and forest land) by the removal of ecological effects of mining. The entrepreneur (according to art. 129, pt. 1 of the Geological and Mining Law Prawo geologiczne i górnicze Dz.U. of 2020, position 1064), is obliged to (inter alia):

- management of the excavation and spoil tips or their liquidation;

- securing or liquidating the equipment and infrastructure of the mining enterprise;

- undertaking activities to protect the environment, i.e.: remediation of soil after ending the mining and bringing back a proper water balance on the surface and in the rock mass.

These are usually areas dedicated to recreation. The directions and possibilities to use the areas degraded by sulphur mining for practical purposes demand detail studies on the properties of the ground (physical and chemical properties), its state (geomorphology), the level of its harmfulness for the environment (getting hydrogen sulphide to the water filling the pit) and possible isolation of harmful layers with non-permeable material.

The article presents the history of the post-mining excavation from its beginning in 1958 till 2012 (second comprehensive inventory of the mining after the end of mining), which, like the Tarnobrzeg Lake in Machów can become an attractive recreational resort, additionally increasing the attractiveness of the region. In this paper the data of the Services and Production Enterprise (Przedsiębiorstwo Ustugowo-Produkcyjne) SIGMA BP sp. z o.o of Tarnobrzeg was used. This company made the surveying inventory of the reservoir and the adjacent areas in: 2005 and 2012. The reclamation of the post-mining area Piaseczno has been carried out since 2005 when the liquidation of the excavation started. The priority was to secure scarps for the planned artificial water body - the Piaseczno Lake. Despite many efforts it was not possible to solve the problem of providing the utility (i.e., recreational) function assumed in the decision of the Head of the Sandomierz District (of 2005). Nowadays it is only a retention reservoir of a controlled level of the water table, and the observed natural and spontaneous succession of vegetation slowly converts this area into a valuable ecological utility.

\section{GEOGRAPHIC AND ADMINISTRATIVE SITUATION OF THE POST-MINING EXCAVATION OF THE PIASECZNO SULPHUR MINE}

The post-mining excavation „Piaseczno” (fig. 1) is a remain of the first (experimental) open cast sulphur mine within the Tarnobrzeg Mining Region - Tarnobrzeskie Zagłębie Siarkowe (TZS). TZS also included the mines in: Machów, Jeziórko, Grzybowo and Osiek (Michno W. et al. 2009). When mining started „Piaseczno" of the area equalling 725.98 ha was situated within the administrative units of: Piaseczno, Krzcina and Przewłoki in the Sandomierz District, in the Kielce Province (Voivodeship). Nowadays the excavation after the liquidated Sulphur Mine "Piaseczno" administratively belongs to the communes of Łoniów and Koprzywnica, the district of Sandomierz, St. Cross (Świętokrzyskie) Voivodeship - fig. 1.

It is situated in the areas of two administrative units, i.e., (according to the Sandomierz Association for the Regional Development - Sandomierskie Stowarzyszenie Rozwoju Regionalnego... [2]):

- rural commune of Łoniów (area: 8 685ha);

- rural-urban commune of Koprzywnica (area: 6 933ha). 


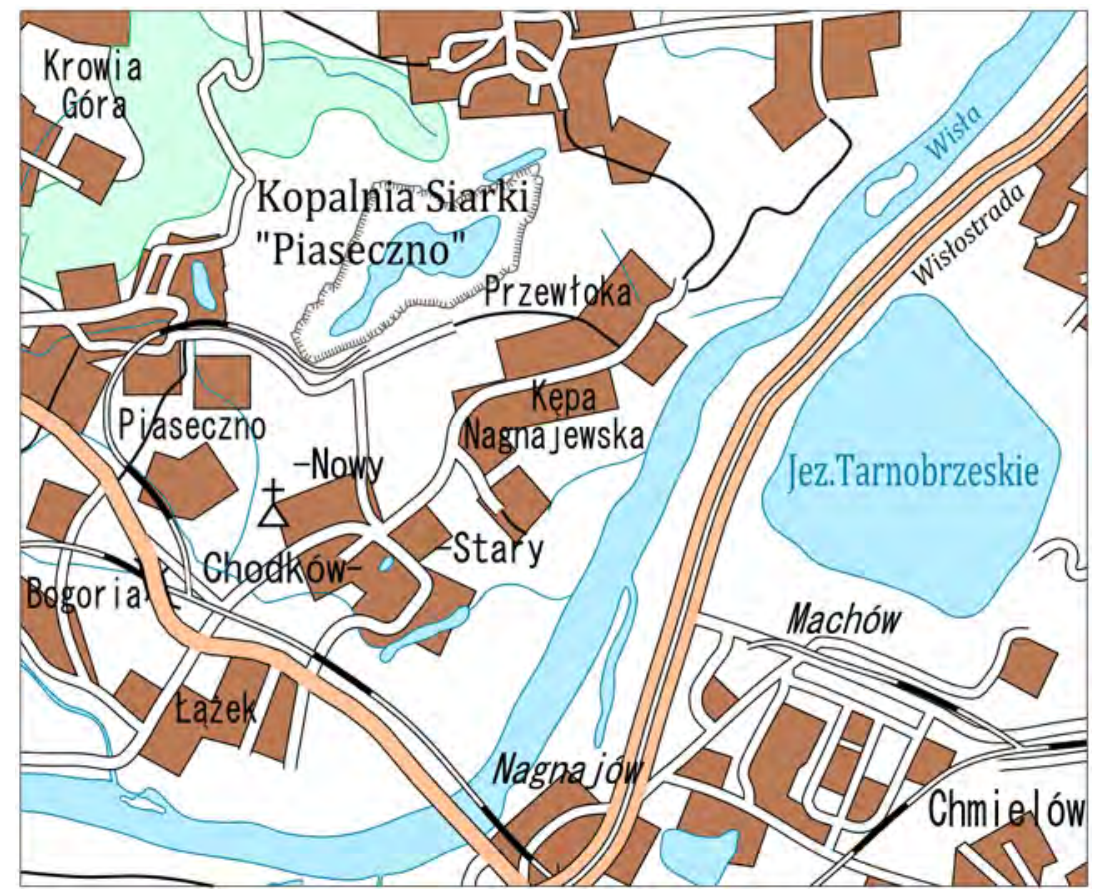

Fig. 1. Location of the post-mining excavation of the Sulphur Mine "Piaseczno" Rys. 1. Lokalizacja wyrobiska pogórniczego Kopalni Siarki „Piaseczno”

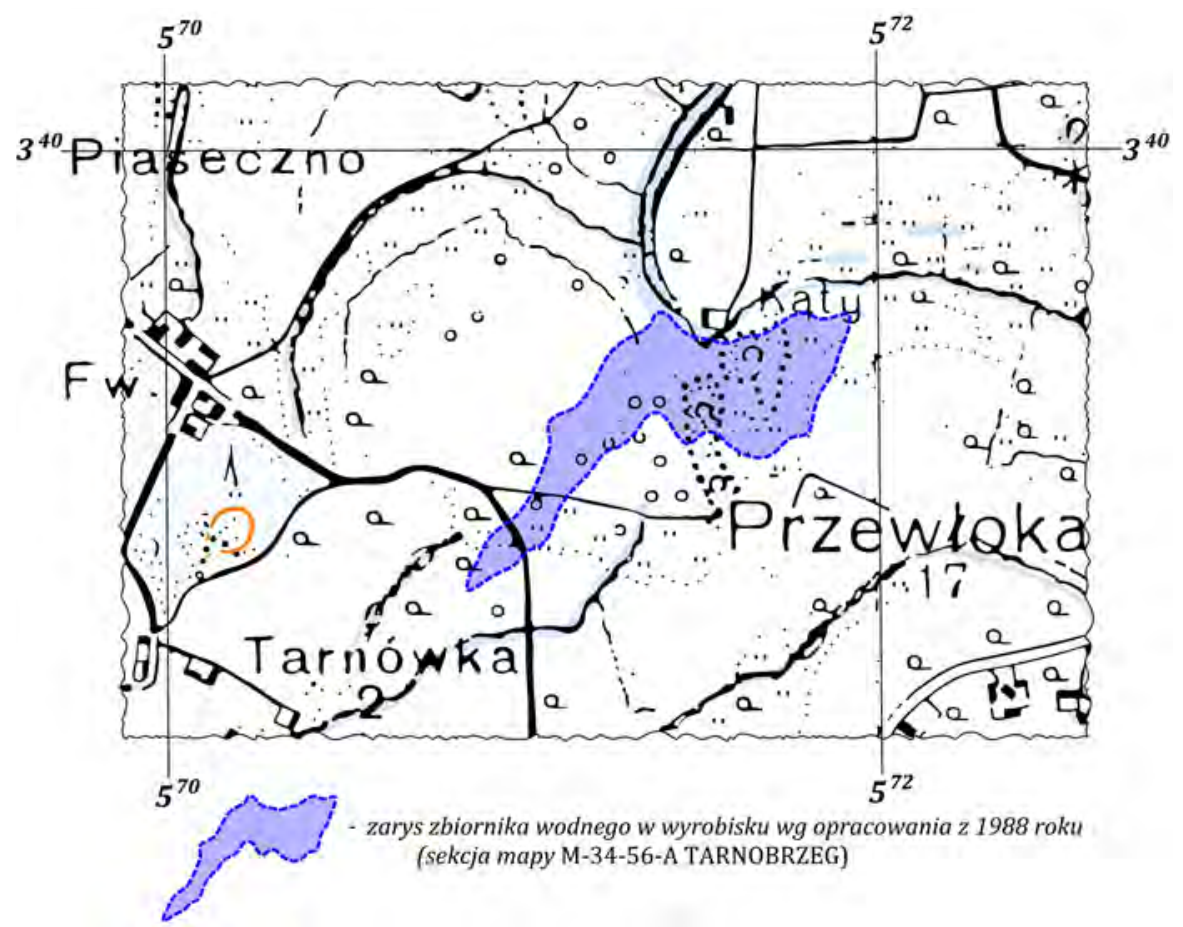

Fig. 2. The outline of the water body Piaseczno according to the state of 1988 shown on the background of the fragment of the archive topographic map in 1:100 000 scale - section 46-33 Sandomierz

Rys. 2. Zarys zbiornika wodnego Piaseczno według stanu na rok 1988 na tle fragmentu archiwalnej mapy topograficznej w skali 1:100 000 - sekcja 46-33 Sandomierz 
The areas of the former Sulphur Mine „Piaseczno” is about 200 ha.

The post-mining area is situated in the areas being the prolongation of the St. Cross Mountains (Góry Świętokrzyskie) within the Połaniec Trough (Niecka Połaniecka), which is a part of the Nida Trough (Niecka Nidziańska) on the terrace of the left bank of the Vistula River in the distance of about $1.5 \mathrm{~km}$ from its riverbed. The border of the mining area covered the areas of highly watered meadows and swamps (very shallow water table), which was shown in a topographic map in 1:100 000 scale - section 46-33 SANDOMIERZ. The outline of the water body according to the paper of 1988, an archive military map 46-33 SANDOMIERZ (made by the Military Bureau in 1941 based on the data of 1938) was illustrated in fig. 2.

\section{GEOLOGY OF THE PIASECZNO MINE REGION}

Growing significance of sulphur in the Polish postwar history caused the discovery of the Miocene sulphur-bearing formations in the region of Tarnobrzeg (the Carpathian Sinkhole). The bedrocks of the elemental sulphur in the Tarnobrzeg Sulphur Region (Tarnobrzeskie Zagłębie Siarkowe - TZS) are gypsum and Miocene anhydrites.

The first test borehole A1 was drilled in Mokrzyszów on the Tarnobrzeg depozit (nowadays a quarter of Tarnobrzeg), where on $28^{\text {th }}$ September 1953 , on the depth of $76 \mathrm{~m}$ the layer of sulphur-bearing rocks was found (Pawłowski S., 1983; Michno W. et al., 2009), making the beginning of the Tarnobrzeg Sulphur Region. Later the deposit was estimated as 560 million tons $(75 \%$ of the whole sulphur resources in Poland - Czajkowski et al., 2012). The Tarnobrzeg sulphur deposit Piaseczno-Machów-Jeziórko-Jamnica belongs to the largest documented world's deposits (Gutman E., Kwiecień K., 1982; Mitura T., 2015).

Originally geological search aimed at exact examination of the deposit was carried out by the Kielce Geological Enterprise (Kieleckie Przedsiębiorstwo Geologiczne - earlier called KPWPG Białogon) and the Geological Works Enterprise (Przedsiębiorstwo Robót Geologicznych) in Warsaw in the region of Piaseczno. That was in 1954-1955, according to the project of 1952 (32 boreholes in the grid of $0.5 \mathrm{~km}$ and $1 \mathrm{~km}-$ Kubica B., Osmólski T., 1964), made by the Geologic
Institute. Despite the limited means for the research and the small number of borehole profiles, in 1954-1956 the team lead by Prof. S. Pawłowski managed to make an accurate outline of the deposit and its parameters in the area of about $18 \mathrm{~km}^{2}$. Further stages of the research proved the accuracy on the data and the parameters found by Prof. Stanisław Pawłowski's team.

Detail examination of the rock mass was carried out already at the stage of making the deposit available, due to the construction of many drainage wells and (documentation) boreholes allowed more precise definition of the amount of the deposit. Moreover, in the bottom area of the excavation after finishing the sulphur mining, and before the start of the mining of the Baranów sands, additionally several dozens of drainage wells were constructed (drainage of the area of mining) and boreholes, in order to estimate the amount of the deposit. Moreover, many boreholes documenting the deposit were also made in the area of the right lobe of the deposit near Machów, which made base for the geological profile. The fragment of the profile covering the excavation of Piaseczno is illustrated in fig. 3.

The post-mining excavation of Piaseczno makes a relic of mining activities of one of the shallowest sulphur deposits in one of two lobes of chemical residues of Świniary - Piaseczno (located alongside the left bank of the Vistula river - the other is situated alongside the right bank of the Vistula: Baranów Sandomierski Tarnobrzeg - Jeziórko; (Pawłowski S., 1956; Sokołowski J. et al., 2016).

In Piaseczno the roof sulphur deposit was close to $14 \mathrm{~m}$ (Pawłowski S., 1983). This prompted the decision to open the mining there (Pawłowski S. et al., 1965). Despite the apparently small depth of the deposit, no traces of sulphur were found underground.

Detail geological studies documented geometric asymmetry of the Vistula. The upper zone of the geological profile in the region of the excavation is made of permeable Quaternary sand and gravel formations with intrusions of clays and dust formations (Pleistocene and Holocene) of mean thickness 5-10 m (maximum up to $25 \mathrm{~m}$ ). In the Holocene layers near the surface, river and ice-dammed formations are represented by humus sands, loams and clays. Under the layer of Quaternary formations there are Tertiary formations of Miocene, i.e. Krakowiec Pecten clays represented by marly clays and clay-like marls with the intrusions of limestones, marls, siltstones or lime sandstones $10-15 \mathrm{~m}$ thick, 


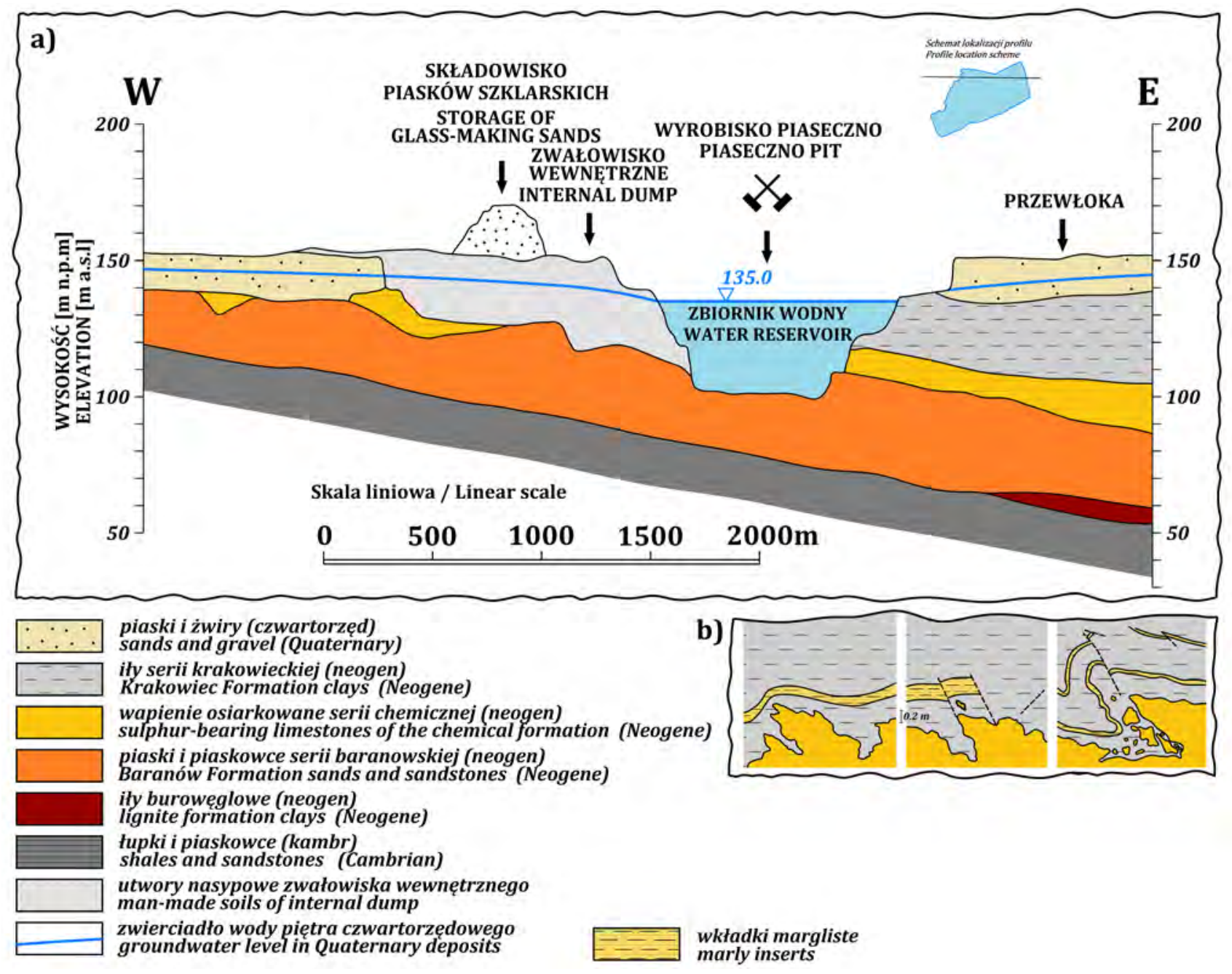

Fig. 3. Geological cross-section by the Piaseczno excavation in W-E direction (Flisiak et al., 2014)

Rys. 3. Przekrój geologiczny przez wyrobisko Piaseczno na kierunku W-E (Flisiak i in., 2014)

where the remains of fauna (bivalves, sea urchins, fish) occurred.

In fact, in the area of the Piaseczno excavation, sulphur-bearing limestones are separated from black clays (often with irregular intrusions of sulphur-bearing limestones or cavern limestones), usually with an irregular layer of waste limestones of changeable thickness from 0 to $1 \mathrm{~m}$.

Below there are formations of so-called chemical series, i.e., 4-18 $\mathrm{m}$ thick sulphur-containing limestones with marle and clay intrusions (Nieć M., 1970), which lay on the layer of Baranów sands). The geological balance of these resources is about $788000 \mathrm{t}$ (source: http://geoportal.pgi.gov.pl/css/surowce/images/2012/ pdf/surowce_szklarskie_2012.pdf); and the thickness of siltstones and poorly compacted sandstones is up to $40 \mathrm{~m}$. On larger depths there are layers of older bed represented by Cambrian shales (Flisiak J. et al., 2014).

Discovering the deposit during the removal of the overburden allowed exact characteristic of the contact zone of sulphur-bearing limestones covered with clays. The contact line was then defined as ,outstandingly" uneven with many cases of subsidence and elevation looking like domes, bumps, mushrooms or clubs with large amplitudes, up to several metres and very steep slopes, sometime vertical or "hanging" (fig. 3b - Nieć M., 1970). These forms made sequences of approximately latitudinal direction E-W or SEE-NWW. The relief of the contact zone was formed as a result of karst processes, which is reflected in the geometry of subse- 
quent subsidence. Their shape is oval and they make drainless zones. Geometrically various roof forms of sulphur-bearing limestones were intensively damaged already after the formation of the deposit. As Percovich M.G. i Markovich L.P. (1966) state, variable relief of the roof of sulphur deposit caused considerable damage at taking the overburden, as a result of removing the uplifted parts of limestones and diminishing the deposit by the clays accumulated in subsidence areas. Moreover, highly disturbed microtectonic zones of the overburden in the layer of pecten clays with large-radius deflections of the layers and the series of vaults, made open-cast mining even more difficult. In the cracked clays, slide planes make foundations of numerous landslides, especially when the inclination of separation planes (cios, stratification) is compliant with the slope of the scarp. The knowledge of the morphology of the deposit roof and the location and range of disturbance in the overburden is the prediction of the landslides.

A detail geological cross-section was illustrated in fig. 3.

\section{HYDROGEOLOGY OF THE REGION OF THE PIASECZNO MINE}

In the region of the mined sulphur deposits and the Baranów sands there are two water-bearing floors: Quaternary and Tertiary. The drainage of the Quaternary floor made water in the neighbouring household wells disappear. The Tertiary water-bearing horizon is made of the series of Baranów fine-grained sands with occasional thing intrusions of sandstone. The thickness of the water-bearing complex is about $33 \mathrm{~m}$. At the moment of the end of sulphur mining the water table lowered to the level of about $2.5 \mathrm{~m}$ below the excavation level. Moreover, intensive drainage of excavations in Piaseczno and Machów with the use of highly efficient pumps during the mining of both lobes of the sulphur deposit led to do the formation of the depression funnel. According to the definition of the depression funnel contained in the Hydrological Dictionary (,Słownik hydrogeologiczny" - Bocheńska T. et al., 1997) is a "zone of the lowered water table of underground waters in the water-bearing level, influenced by the drainage of the mine". The limit of the range is considered such a distance when the water table under the influence of drainage was lowered by $1 \mathrm{~m}$, referring to the mean level within several years. The hydrogeological profile of the excavation in the W-E direction (Raport NIK, 2018) was presented in fig. 4 .

The drainage of both excavations caused the dehydration of originally wet areas (green utilities, arable land), situated within the range of drainage. This changed the land use. Unfavourable soil conditions changed. The areas that used to be wetlands spontaneously changed into fertile arable land of $1^{\text {st }}$ and $2^{\text {nd }}$ complex of usefulness, i.e., the highest productivity. Original fallow land was mainly adapted for orchards and development.

From ending the sulphur mining and glass sands, the most important problem is keeping the level of the water table. Damming makes problems with maintaining the stability of scarp excavation. Particularly sensitive to the disturbance of stability resulting from the movement of the water table and changes in the humidity of the landslide grounds are scarps formed from the overburden in the region of internal repository, i.e., in the north-west part of the excavation (Flisiak J. et al., 2014). The degree of loosening the mixture of the landslides grounds (non-cohesive and cohesive) and increase of their density in practice lower the resistance to cutting (Rybicki S., 1986). This is not the case in original (intact by mining) structures, which are homogenous in lithological and facial aspect. In such cases, the assessment of geological, physical and mechanical properties and the assessment of the stability of scarps, the changes of humidity and the level of the water table are difficult in forecasting the stability analysis.

Since the end of the reclamation of the excavation of Machów, the drainage of the surface has been carried out in Piaseczno, keeping the water table on the steady level, defined in the reclamation plan. The main source of watering the Quaternary water-bearing formations is infiltration of precipitation waters, which define hydrological conditions in the region of Piaseczno.

Unfavourable topography of the area adjacent to the liquidated of the mining enterprise, long-lasting development, the lack of the drainge network in the communes of: Łoniów, Koprzywnica and Samborzec make the Sulphur Mine „Machów” (w liquidation) permanently keep a relatively steady level of the water table in the excavation. Consequently, this halts the process of restoring water balance due to the depression funnel. Hydrological studies confirmed the presence of excavations: Piaseczno and Machów and their drainage, led to the change of the situation of the water table of the value higher than $1.0 \mathrm{~m}$ in the area of $31 \mathrm{~km}^{2}$. 


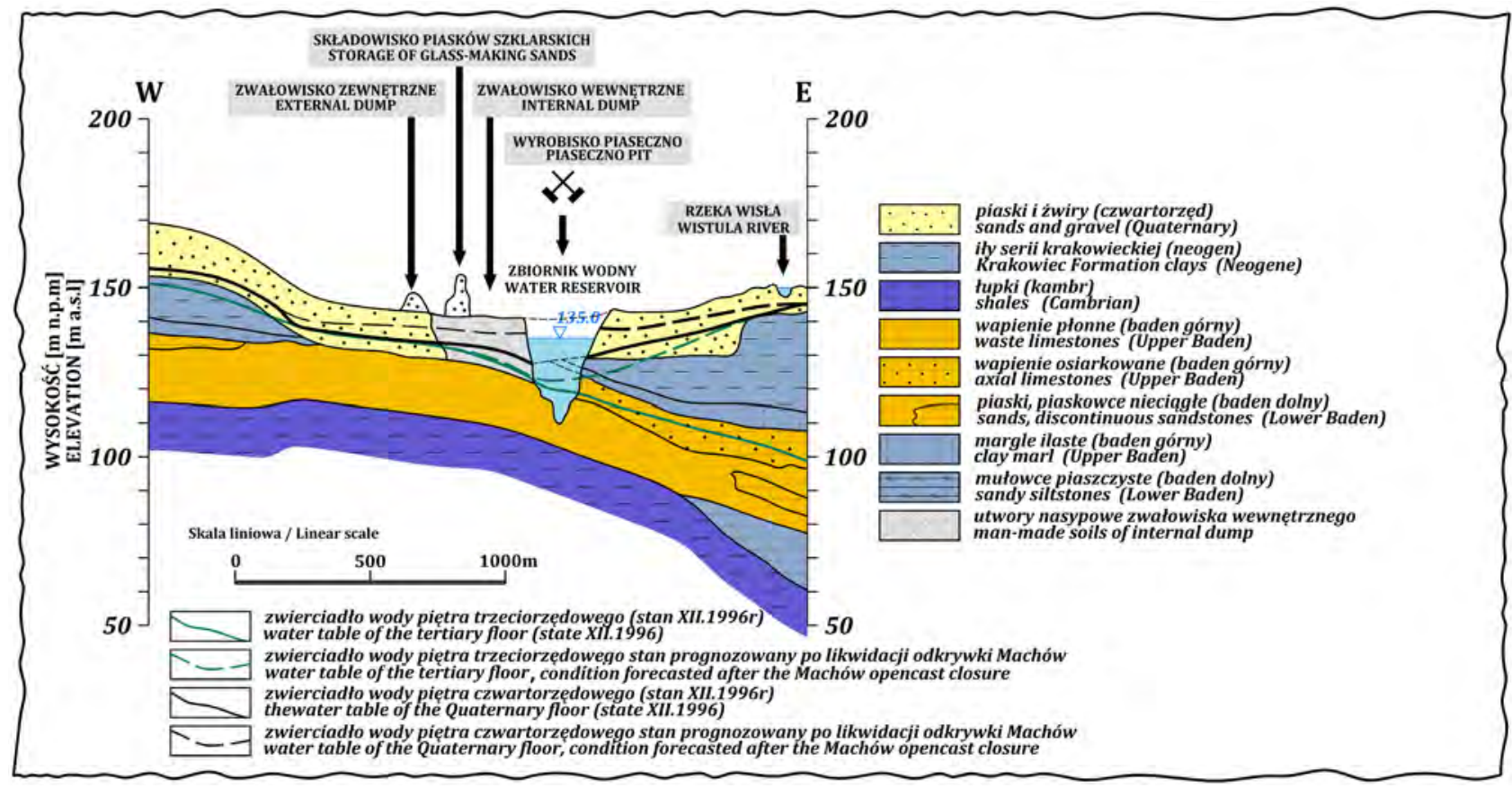

Fig. 4. Hydrogeological profile through the excavation of Piaseczno in W-E direction (the Supreme Control Chamber 2018) Rys. 4. Przekrój hydrogeologiczny przez wyrobisko Piaseczno na kierunku W-E (Najwyższa Izba Kontroli 2018)

The liquidation of the depression funnel by the restoration of the original level of waters to the ordinate $\sim+146.0 \mathrm{~m}$ a.s.1., today poses potential threat to the areas of three communes of the Sandomierz District. The construction of a proper water supply and drainage system in the areas situated in the depression funnel of the liquidated excavations, would practically solve the problem of the inundation threats, and the area of shallow depth of the water table in the depth of $0.5-1.0 \mathrm{~m}$ p.p.t would be limited to about $1.6 \mathrm{~km}^{2}$ (Szmuc M., Madej K., 2010).

Despite the inundation threat in the large area of the grounds in case of the lack of the water supply and drainage system, at the moment of bringing back the original level of ground waters, the new water reservoir perfectly meets the requirements of environment and economy of the region. According to Ciupa T., and Suligowski R., (2018), in the Polish uplands, a clear water deficit is observed. For there are no natural water bodies that could play the role of retention reservoirs, it is necessary to construct small-retention reservoirs, which would improve the characteristics of the water bodies in the region. In the same St. Cross (Świętokrzyskie) voivodeship in rural areas it was planned to construct 173 small-retention water bodies (including 20 exceeding the volume of 1 million $\mathrm{m}^{3}$ ), mainly multi-function (retention-recreation, anti-flood with the energy function and angling function). The majority of them have already been constructed and a small part of them are nowadays being made (Ciupa T., Suligowski R., 2018).

The Piaseczno reservoir belongs to the water bodies of average retention, which is particularly significant to improve water resources in the catchment of agricultural and forest communes of: Łoniów, Koprzywnica and Samborzec, as well as the limitation of the effects of droughts and floods. Moreover, it contributes to the increase of biodiversity of the area, and consequently, to the increase of the ecological meaning of the region.

\section{HISTORY OF THE SULPHUR MINE „PIASECZNO”}

1950s was the period of intensive restoration of the war-destroyed country and convincing geological services about a huge potential of the Tarnobrzeg sulphur deposit, which was to change chemical industry in Poland, where the crisis of sulphur-bearing resources was experienced. The search was ,hidden from the public" when spatial planning was treated in a stereotypic 
way, considering only physical character of the Earth surface. New approach in spatial planning considered locations of projects crucial to the economy (roads, railways, electric wires, residential areas, dams, power plants, etc.), taking into account the documented sulphur deposits.

As a result of the carried out (limited) field work, in 1955 the Report (Komunikat) was issued and the presence of an outcrop with sulphur-bearing limestones in Piaseczno-Jasienica was announced. On $22^{\text {nd }}$ November 1955 a report: Geological Foundations for the Studies and Search in the area of Piaseczno (Założenia geologicznych badań i poszukiwań w okolicy Piaseczna) was published; and already a month later $\left(20^{\text {th }}\right.$ December 1955) one more Komunikat on the discovery of sulphur deposit in Piaseczno was published (Pawłowski S., 1983).

As a result of the geological research carried out by the Geological Institute in the region of Piaseczno-Krzcina-Przewłoki, the authorities of the Polish People's Republic, in the framework of the construction and implementation of the Six Years' Plan of the Polish People's Republic (Pawłowski S., 1983), made crucial decisions referring to the left-bank lobe of the deposit.

By the Decision of the Minister of Chemical Industry of $24^{\text {th }}$ May 1958 based on:

- art. 26 Mining Law of $6^{\text {th }}$ May 1953 (Dz.U. no. 10 , position 65 , uniform text of 1955);

- $\$ 19$ enactment of the Council of Ministers (Government) of 27 March 1954 (Dz.U. no. 14, position 52) referring to mining areas;

- geological documentation of the elemental sulphur deposit in Piaseczno near Koprzywnica of $9^{\text {th }}$ August 1956 (Pawłowski S., 1983);

in the vicinity of the left-bank of the Vistula river, the mining region „Piaseczno” was formed and the mining of the sulphur deposit started. First earth works carried out according to the project carried out by the team led by Stanisław Orzechowski (M.Sc., Eng), were connected with the removal of the overburden to make the deposit available. By the decision of the Ministry of Chemical Industry, the works started on $9^{\text {th }}$ July 1956 and excavators were used (Kubica B., Osmólski T., 1964). The enterprise authorized to carry out the mining of the elemental sulphur deposit was called Sulphur Mining and Processing Enterprise (Kopalnie i Zakłady Przetwórcze Siarki) „Tarnobrzeg” (KiZPS started their work on 1 July 1954). It is worth noticing that in 1958, according to the agreement between the Minister of Chemical Industry, and Minister of Culture and Art „sulphur" indirectly became a patron of the arts and protector of the Polish cultural monuments, participating in the costs of the renovation of the neighbouring Castle (called "Little Wawel") in Baranów Sandomierski. The agreement gave guarantee that the sulphur industry will be given the castle after the end of its revitalisation. The renovated object was opened on $20^{\text {th }}$ December 1966 (Gutman E., Kwiecień K., 1992).

Initial stage of the mine construction, including drainage and geologic-engineering works was carried out by the Warsaw Geological and Engineering Enterprise (Warszawskie Przedsiębiorstwo Geologiczno-Inżynierskie), and as early as in 1957 the removal of overburden and its piling as well as the drainage of the excavation was carried out by the Mine Construction Enterprise (Przedsiębiorstwo Budowy Kopalń) of Warsaw. The speed of the work connected with overburden removal and transport to the outer repository was so high that already on $4^{\text {th }}$ December 1957 the deposit of elemental sulphur (Pawłowski S. et al., 1965) was uncovered and the mining of the first tons of sulphur-bearing limestones took place, which was a key-factor in finding the technology of the enrichment of the product and actually the front of preliminary mining was opened (Kubica B., Osmólski T., 1964). The stage of preliminary mining was in December 1960. It took three years to prepare normal planned mining of sulphur ore. On $4^{\text {th }}$ December 1960 regular mining of sulphur-bearing limestone started.

A large scale of the project can be seen in the numbers. Only until 1964 over 800000 t of sulphur (only in 1964 the production of sulphur reached almost $300000 \mathrm{t}$ ) out of 2.5 million $\mathrm{t}$ of the ore were taken, and only in mid 1965 the millionth ton of sulphur left the refining facility (Kubica B., Osmólski T., 1964). The archive data show that the mining abilities of the mine in the full cycle of the work (multi-shift) were about 3 million $\mathrm{t} /$ year. Large scale of sulphur industry flourish in Piaseczno in 1960s and 1970s was caused by a great world's demand for sulphur, which lead to organizing further enterprises in Machów, Jeziórko and Osiek. Poland became a leading producer and exporter of sulphur.

The carried out mining of the sulphur mine and its processing was characterized by great level of nuisance to the natural environment (Szmuc M., Madej K., 2011). 


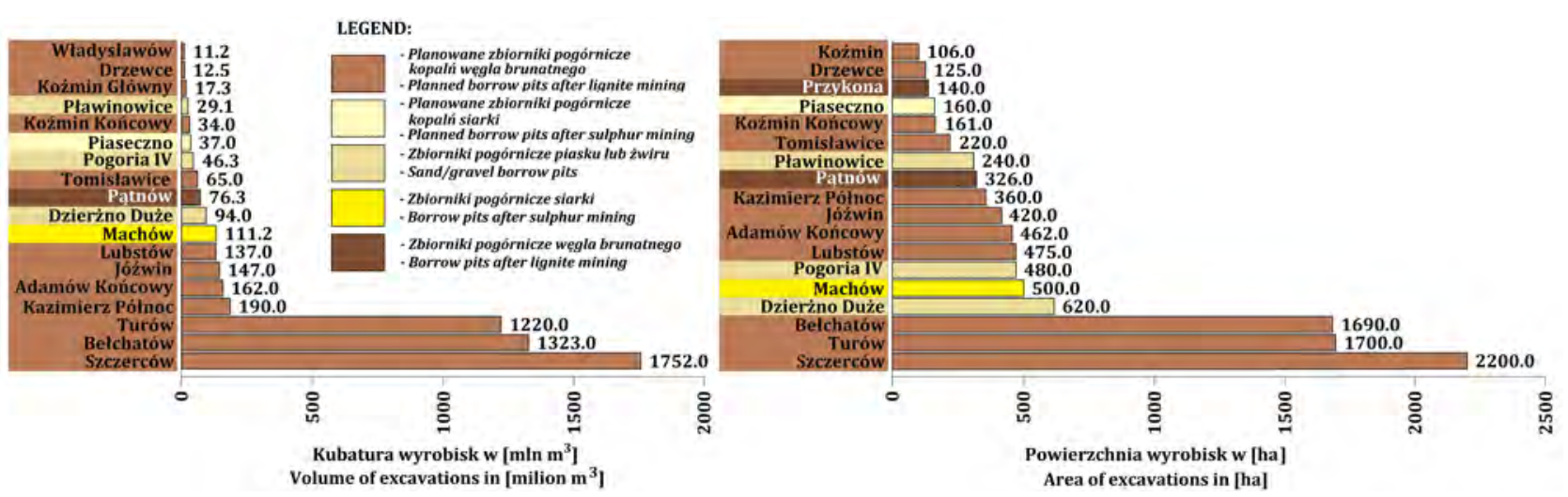

Fig. 5. Statistics of the largest post-mining excavations in Poland in terms of volume and area (author's own work based on Galiniak G. et al., 2014)

Rys. 5. Statystyka największych wyrobisk pogórniczych w Polsce pod względem wielkości kubatury i powierzchni (opracowanie autora na podstawie Galiniak G. et al., 2014)

A system of mining was based on the scheme of excavator - conveyor belt - loader (in Polish KTZ system koparka - taśmociag - zwałowarka), which was later implemented in the Sulphur Mine „Machów”, as a reliable and relatively efficient system. The excavations of Piaseczno and Machów belonged to the largest opencast mining areas of this kind (flotation-refining method of mining elemental sulphur deposit). Also in the scale of the whole mining industry in Poland, post-sulphur excavations of Piaseczno are among the largest in volume and area, which was illustrated in the graph - fig. 5 .

This resulted from the size of recognised and documented elemental sulphur deposits in Poland, thus the excavations were also very large. The mining of sulphur ores lasted since 1950s until the second half of 1990s (KS Machów). In case of KS Piaseczno, running out the sulphur deposit ended the sulphur mining in 1971 (Buczek Z. et al., 2010; Szmuc M., Madej K., 2010). Altogether 17.2 million $t$ of the ore were mined and about 3.4 million $t$ of sulphur were produced (Michno W., 2009).

The mining in the sulphur mine in Piaseczno ended in 1971, but still for 10 years the deposits under the layer under the exploited sulphur ores of the Baranów formations (glass sands), which made the material for glass production in the Glassworks in Sandomierz. By the decision of the President of the Central Bureau of Geology in Warsaw of October 1972, geological balance resources in $\mathrm{C}_{1}$ category of quartz sands (quality of the resource within the range predicted for category $\mathrm{B}$ ) used in glass industry, were estimated as 7144000 tons.
This was the last decision allowing a mine to enlarge the excavation Piaseczno in the framework of the planned mining.

During the liquidation of the Sulphur Mine „Piaseczno", in 1972 a decision was made to transfer to the Sulphur Mine „Machów” through the Vistula River a 1350-tons' bucket excavator K-800, in the framework of operation „Przerzut II" [Transfer II]. This was a very difficult and expensive pioneer logistic operation on a European scale, carried out by the Military Communication Forces, owing to a specially designed temporary bridge (1980 wooden posts were stuck on the bottom of the Vistula river).

By the decision of the Vice-Minister of the Chemical Industry of March 1973 is made on the perspective of mining the Baranów sands from the bottom of the exploited sulphur open-cast mine in the Work Plan of the „Machów - Piaseczno” Mine for 1974-1975 (part II) and the Annex to the Plan... [1]. In the content of the decision a note was given that proper technical and organizational conditions should be provided so that the mining of sands could end in time and the excavation of the Piaseczno Mine could become a repository of post-flotation wastes. Thus before starting the mining of aggregates a drainage of the mining area was carried out in two stages, under the supervision of the mine surveying services. Several dozens of boreholes of Tertiary wells were made. Their mean depth was $32 \mathrm{~m}$. They were equipped with filters of from pipes $11 \frac{3}{4}$ " diameter, perforated in gravel coating of granulation $0.8-2.0 \mathrm{~mm}$, equipped with submersible pumps GB-100. 
The carried out geological studies allowed the documentation of glass sands (Baranów sands) under the deposit, mined until 1981 and deposited within the borders of internal repositary (56 ha - fig. 6) for the needs of the Glassworks in Sandomierz (nowadays Pilkington Sandoglass S.A). Parallel to mining the Baranów sands, KiZPS ,Siarkopol” carried out the reclamation of the outer and inner repository, which ended in 1978. The result of these works was giving 160 ha of the reclaimed area to the Polish Forest Holding (Lasy Państwowe). Still during the mining of the Baranów sands (1980-1982) KiZPS ,Siarkopol”, within the borders of the excavation, mining works and active drainage allowed the mining of the sands under the deposit from its bottom. One year after ending the mining of the Baranów sands in 1982, by the decision of the Minister of Chemical and Light Industry the mining area OG Piaseczno was abolished.

In 1982 the Minister of Chemical Industry and Trade signed the document on the liquidation of the mining area Piaseczno and indicated the direction of the management of the excavation. This was because the min- ing of sulphur and Baranów sands mined for the Glassworks in Sandomierz ended. Economic situation in those times and the limited knowledge on the properties and the possibilities of economical utilization of hearth wastes, contributed to the decision on converting excavation "Piaseczno" into the landfill of industrial wastes.

After ending the mining, the volume of the mine defined based on cartographic materials of those times made in 1:2000 scale was about 35 million $\mathrm{m}^{3}$. Such a large size of the liquidated mine, the attempts to utilize such a problematic legacy by the Power Plant „Połaniec" and economic calculations caused the decision to adapt the mine as landfill. The lack of the idea of non-mining and non-industrial management of the excavation contributed to the decision to deposit wastes in that area. On $28^{\text {th }}$ February 1986 the excavation area was given by the Tarnobrzeg enterprise Sulphur Mines and Refining Industry (Kopalnie i Zakłady Przetwórcze Siarki) „Siarkopol” to the Tadeusz Kościuszko Power Plant (Elektrownia im Tadeusza Kościuszki S.A.) in Połaniec, which planned the adaptation of the post-min-

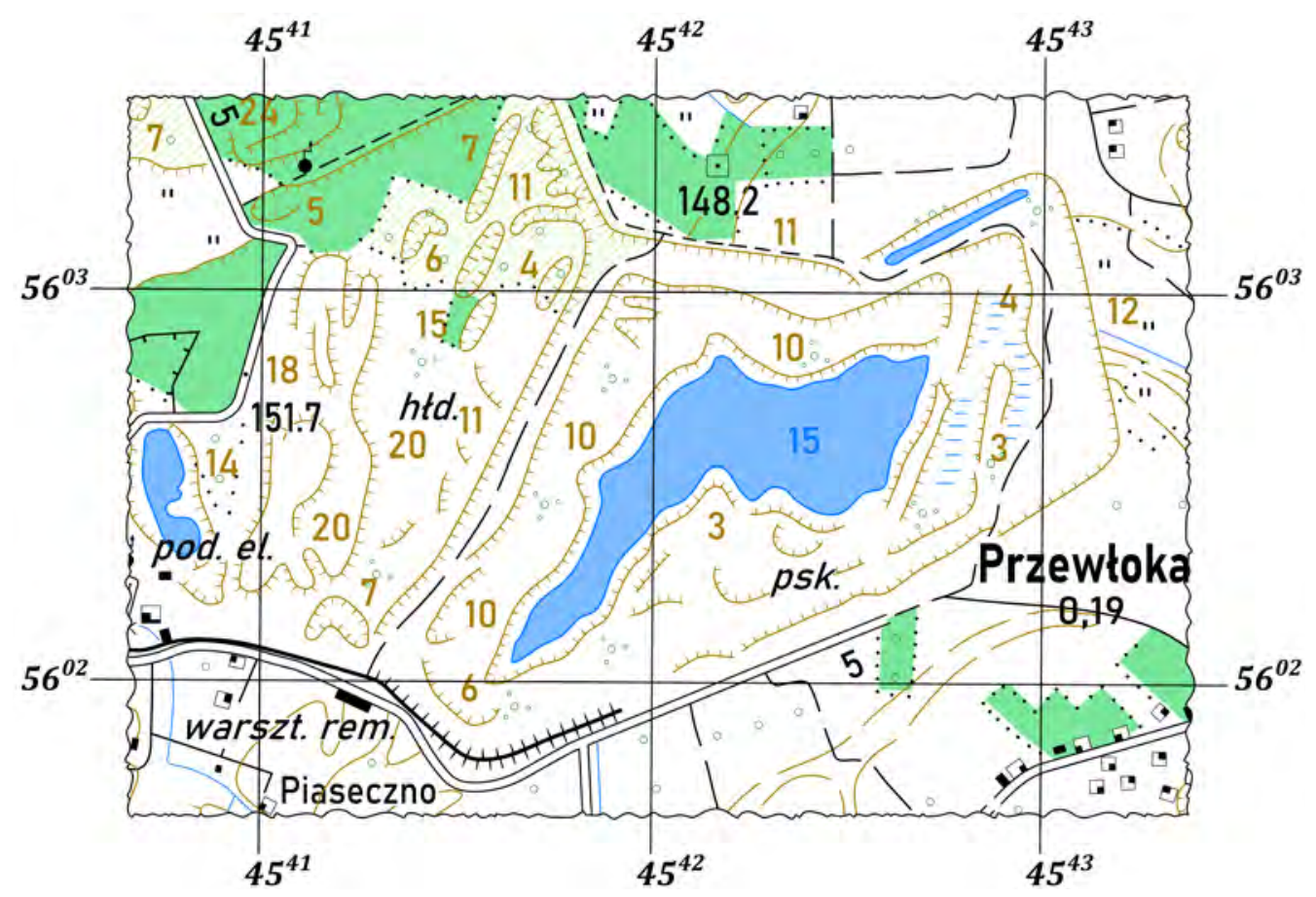

Fig. 6. The fragment of the military topographic map in scale 1:50 000 (in the system of flat coordinates 1942 and altitude co-ordinates Kronsztadt) illustrating the region of studies (emblem: M-34-56-A TARNOBRZEG) according to the state of 1988 (author's own work based on the map)

Rys. 6. Fragment wojskowej mapy topograficznej w skali 1:50 000 (w układzie współrzędnych: płaskich 1942 i wysokościowej Kronsztadt) ilustrującej rejon badań (godło: M-34-56-A TARNOBRZEG) według stanu na rok 1988 (opracowanie autora na podstawie mapy) 
ing area for deposition of hearth wastes. The power plant paid the costs of drainage, securing the slopes of excavation and took the duty of its reclamation in the framework of financial means transferred by KiZPS „Siarkopol” (Michno W. et al., 2009).

On the request of the stakeholders, i.e. the authorities of the mine and power plants, a full and detail hydrogeological documentation was made to take further actions in order to use the excavation for industrial purposes. According to the accepted premises, the mining excavation was to be filled with hearth wastes (slags, fly ashes and blends of ash and slag) coming from burning hard coal. In those times technological wastes from the cogeneration plants (nowadays defined as industrial side product, Polish: uboczny produkt przemystowy UPP - Sybilski D. et al., 2004) were treated as partially useful from economic point of view. Fly ashes were used for the production of cement, construction ceramics (fine elements), while slag was treated as useless wastes. Today all the hearth wastes, including slag are massively applied in construction industry as aggregates and perfect material to build roads and pavements (hard surface). The economic situation of those times and limited knowledge on the properties and possibilities of economic use of hearth wastes contributed to issuing the decision on making „Piaseczno” excavation the landfill of industrial wastes.

Until the moment of transferring the mining area to the „Połaniec” power plant, the former user's task was to maintain the constant level of ground waters from the bottom of excavation on the level of $106 \mathrm{~m}$ a.s.l. The excess of water was consequently pumped to the Vistula. River. In those times the system of securing scarps of excavation from the excessive impact of Quaternary waters meant making at the foot of the upper scarp, on the level of the first shelf of band trenches collecting the excess of water and pumping it in a controlled way on the bottom of the mine, where they mixed with Tertiary waters.

Table 1. Selected morphometric parameters of the water body Piaseczno, defined based of the topographic map, scale 1:50 000 (emblem: M-34-56-A TARNOBRZEG) according to the state of 1988)

Tabela 1. Zestawienie wybranych parametrów morfometrycznych zbiornika wodnego Piaseczno, określonych na podstawie mapy topograficznej w skali 1:50 000 (godło: M-34-56-A TARNOBRZEG) wg stanu na rok 1988)

\begin{tabular}{|c|c|c|c|}
\hline \multicolumn{2}{|c|}{ Morphometric Parameter } & \multirow{2}{*}{$\begin{array}{c}\begin{array}{c}\text { Symbol of the } \\
\text { Parameter }\end{array} \\
X_{\mathrm{s}}, \mathrm{Y}_{\mathrm{s}}\end{array}$} & \multirow{2}{*}{$\begin{array}{l}\text { Value of the Parameter } \\
5602556.90,4542229.40\end{array}$} \\
\hline \multirow{2}{*}{$\begin{array}{l}\text { Location } \\
\text { of the water body }\end{array}$} & $\begin{array}{l}\text { geodetic coordinates of the centre } \\
\text { in system } 1942\end{array}$ & & \\
\hline & geographic coordinates of the centre & $\mathrm{B}, \mathrm{L}$ & $50^{\circ} 33^{\prime} 07.52^{\prime \prime}, 21^{\circ} 35^{\prime} 38.80^{\prime \prime}$ \\
\hline \multicolumn{2}{|r|}{ Area of the water body } & $\mathrm{P}$ & $\begin{array}{l}257790 \mathrm{~m}^{2} \\
25.78 \mathrm{ha}\end{array}$ \\
\hline \multicolumn{2}{|c|}{ Maximum depth of the water body } & $\mathrm{G}_{\max }$ & $-15.00 \mathrm{~m}$ \\
\hline \multicolumn{2}{|r|}{ Maximum length $(*)$} & $\mathrm{L}_{\max }$ & $1436 \mathrm{~m}$ \\
\hline \multicolumn{2}{|r|}{ Maximum width $(*)$} & $\mathrm{S}_{\max }$ & $331 \mathrm{~m}$ \\
\hline \multicolumn{2}{|c|}{$\begin{array}{l}\text { Azimuth of the elongation of the water body } \\
\text { (mean - according to the scheme) }\end{array}$} & $\mathrm{A}_{s \mathrm{sr}}$ & $68^{\circ} 26^{\prime}$ \\
\hline \multicolumn{2}{|r|}{ Shoreline length } & $\mathrm{L}$ & $3206 \mathrm{~m}$ \\
\hline \multicolumn{2}{|r|}{ Scheme $(*)$} & & \\
\hline
\end{tabular}

Source: work by R. Gawałkiewicz 
Based on the archive topographic map in scale 1:50 000 (emblem: M-34-56-A TARNOBRZEG - fig. 6), basic morphometric parameters of the water body were established and put in table 1.

On the other hand, based on the analysis of an archive map topographic map obtained from the geoportal (source: www.mapy.geoportal.gov.pl/imap), presented in a fragment in fig. 7, basic_morphometric parameters of the water body were given. The morphometric data were put in table 2 . The growth of the value of morphometric parameters and chaotic character of the surface document the state of excavation in 1990s.

Already in 1987 it was estimated that keeping the energy production at a constant level, the excavation of Piaseczno would be filled for about 20 years, which means it would have been left without a trace by now. The planned technology of hearth waste deposit was a hydraulic method, using local waters in a closed cycle. That would mean that the excess of water would not be pumped to the Vistula; but the carried out analyses indicated a significant elevation of the water table in the reservoir. To provide safe conditions of the use of both excavations, i.e., Piaseczno and Machów, they were treated as communicating vessels and the limit of the water level in „Piaseczno” was established $+140 \mathrm{~m}$ a.s.l.

In 1987 a project of the management of not functioning post-mining excavation was prepared for the needs of the Tadeusz Kościuszko Power Plant „Połaniec”, located about $25 \mathrm{~km}$ from post-sulphur excavation. In the framework of the carried out project [3], it was

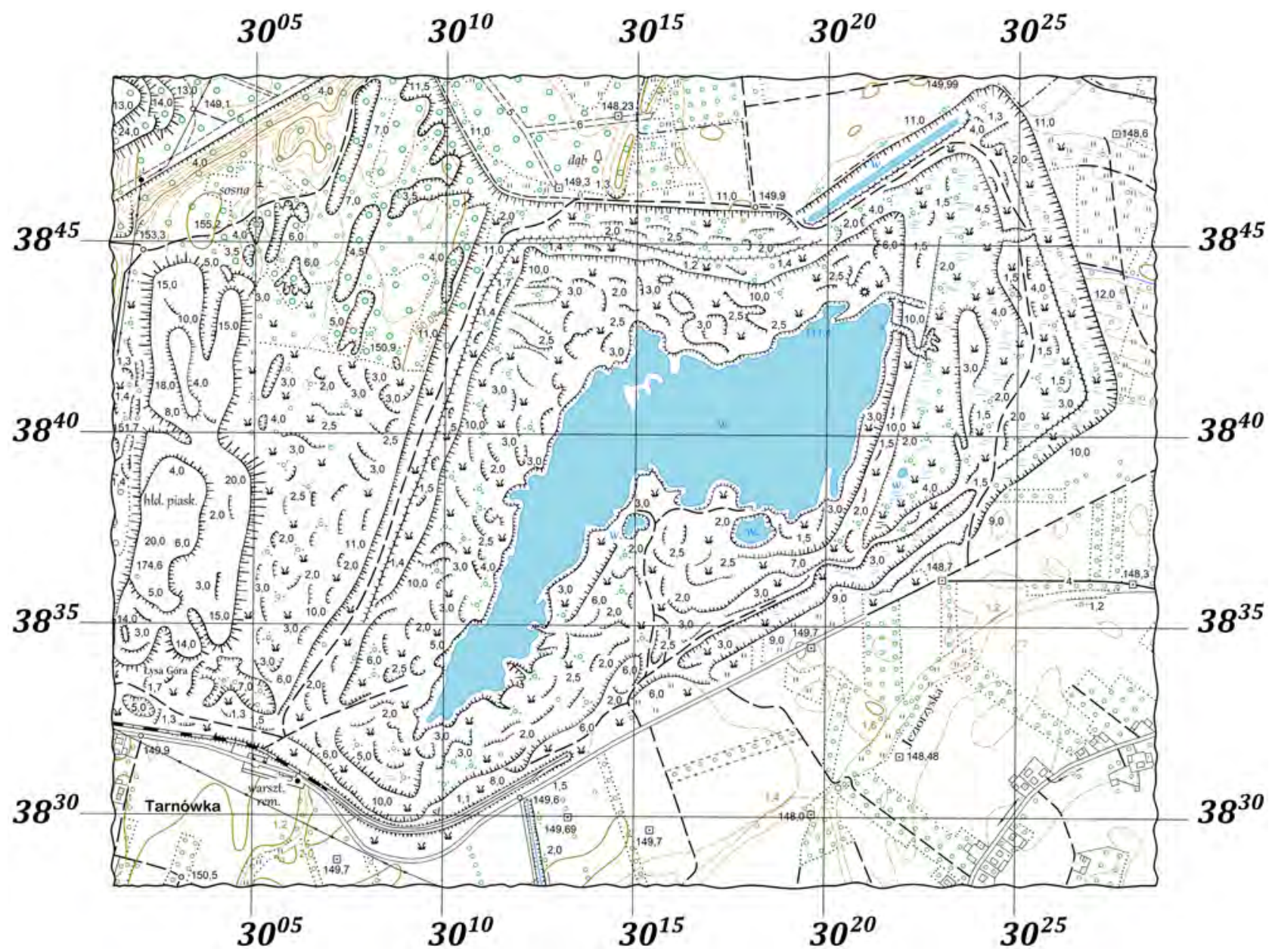

Fig. 7. The fragment of a topographic map illustrating the study area (author's own work based on the map of www.mapy.geoportal.gov.pl/imap)

Rys. 7. Fragment mapy topograficznej ilustrującej rejon badań (opracowanie autora na podstawie mapy z www.mapy.geoportal.gov.pl/imap) 
Table 2. Morphometric parameters of the water body Piaseczno, based on the topographic map obtained from www.mapy. geoportal.gov.pl/imap

Tabela 2. Zestawienie wybranych parametrów morfometrycznych zbiornika wodnego Piaseczno, określonych na podstawie mapy topograficznej pozyskanej z www.mapy.geoportal.gov.pl/imap

\begin{tabular}{|c|c|c|}
\hline Morphometric Parameter & $\begin{array}{c}\text { Symbol } \\
\text { of the Parameter }\end{array}$ & Value of the Parameter \\
\hline Area of the water body & $\mathrm{P}$ & $\begin{array}{c}38495 \mathrm{~m}^{2} \\
38,49 \text { ha }\end{array}$ \\
\hline Maximum depth of the water body & $\mathrm{G}_{\max }$ & no data available \\
\hline Maximum length $\left(^{*}\right)$ & $\mathrm{L}_{\max }$ & $1719 \mathrm{~m}$ \\
\hline Maximum width $\left(^{*}\right)$ & $\mathrm{S}_{\max }$ & $410 \mathrm{~m}$ \\
\hline Shoreline length & $\mathrm{L}$ & \\
\hline Scheme $\left(^{*}\right)$ & \\
\hline
\end{tabular}

Source: work by R. Gawałkiewicz

necessary to do geological studies to define the stability of scarps in the conditions of not mined excavation, the degree of the impact of the deposed wastes on the quality of ground waters and the possibility of building the constructions of technological infrastructure, discharging platforms, floating sets of pumps etc. For the protection of the environment it was necessary to carry out hydrogeological studies on the Quaternary and Tertiary formations and the installation of piezometers in the boreholes of the depth between 6 and $42 \mathrm{~m}$ in the amount of 52 items of the total length of $927.2 \mathrm{~m}$.

The plans to convert post-mining areas into the repository of post-industrial wastes were, however abandoned. This was the effect of the protests of the residents and local authorities. Thus, over the years the excavation was filled with Quaternary and Neogene formations and required permanent technical services. The complex of pumps kept relatively constant level water table, which provided security for the residents of the households situated below the water table.

Already in those times the excavation was in its larger part filled with water. With the adjacent areas it was not fully reclaimed and managed for other purpose than mining. Thus in 1994 by the Enactment no. 5 by the
Minister of Industry and Trade of $14^{\text {th }}$ January 1994, the property of one-person S.A. State Treasury Company including the mining areas of Machów and Piaseczno, was unified into one body functioning as a state-owned company called Sulphur Mine (Polish: Kopalnia Siarki) „Machów” in Tarnobrzeg, later known as one-person S.A. State Treasury Company.

The turn of 1980s and 1990s was the time of rapid political changes and the lack of prospects for financing many closed mining enterprises, including those after sulphur mining: Machów and Piaseczno. Economic factors defined the thresholds of profitability of open-cast mining the Polish sulphur deposit. The method was very costly in those times already. A drastic decrease of prices resulting from the drop in demand in the world markets and the decrease in selling meant the decrease of the profitability. Thus a less environmentally invasive borehole method was applied (Jeziórko, Osiek). The situation of open-cast sulphur mining was also affected by the discovery of new sulphur sources - sulphur-bearing natural gas and sulphur-bearing oil (up to 5\% sulphur). Strict international environmental regulations defining the maximum allowed levels of sulphur emission to the atmosphere led to the change in the refining of gas and 
oil. Sulphur became a side product of gas and oil industry, which significantly decreased the prices of mineral sulphur in the world.

With the moment of decision on closing of the Sulphur Mine "Machów" in 1992, the situation required necessary activities of liquidation and reclamation on both banks of the Vistula River. Altogether over 34 years of activities of both mines about 82 million tons of sulphur were mined. From this about 15 million tons of refined sulphur were obtained. Making these two deposits available for mining required the removal of about 380 million $\mathrm{m}^{3}$ of overburden, which was disposed on outer repositories and later on also in excavations.

The attempts of making plans of the liquidation of excavation and its management were made several times. In 1993 the Programme of Restructuring Sulphur Industry in Poland in 1993-2000 (Program restrukturyzacji przemystu siarkowego w Polsce w latach 19932000) was approved. The programme defined the range and character of liquidation and reclamation works in the initial phase and by 1997 the Programme of the Liquidation of the Sulphur Mine Machów, Associated with the Liquidation of the Piaseczno Excavation (Program likwidacji Kopalni Siarki Machów w skojarzeniu z likwidacja wyrobiska Piaseczno) was accepted by the Minister of Economy. It made the element of design works carried out in 1996-2000 covering the preparation for necessary liquidation works. Due to the lack of financial means and lack of administrative and legal decisions connected with the property and use issues, the implementation of the liquidation plans was postponed.

Abandoned excavations with a spontaneously created water body posed environmental threat. The threat resulted from the possibility that waters with a high content of hydrogen sulphide can get to the excavation. The released hydrogen sulphide would make serious danger of the contamination of atmosphere and surface waters (Mitura T., 2015). The decision was made that the bare layer of the deposit should be covered with the isolation layer consisting of the Krakowiec clays and that shelves and sharp should be formed in such a way that their stability is guaranteed. Organized in 1996 contest referring to the proposal of the liquidation of mining excavations in Piaseczno and Machów, the winning project assumed simultaneous and mutually connected liquidation of both excavations and their reclamation in the water direction. The plan assumed that finally two water bodies are made. Their area would be 160 and 455 ha, respectively. With the adjacent areas they were supposed to be managed for recreation. The project referring to the Piaseczno water body assumed that the shores of the reservoir are suitable for sport and recreation (tourist and gastronomic facilities). The recommendations of the project of simultaneous reclamation of excavations in Piaseczno and Machów were not implemented, which was noted in the post-control report of the Supreme Control Chamber (Najwyższa Izba Kontroli, 2018)). According to the formed by NIK expert team, abandoning simultaneous reclamation of both excavations was a serious mistake. Carrying out reclamation works only in the Machów excavation made the implementation of the reclamation plans in Piaseczno more difficult, due to broad indirect and complicated hydrological connections between them.

In 2004 the Sulphur Mine „Machów” was called to liquidate (dismantling machines and other equipment) of its mining industry, including Piaseczno and to carry out their reclamation (Szmuc M., Madej K., 2010). Then, by the decision of the head of the Sandomierz District the recreational character of reclamation was established for the surface of inner repository and the tree and meadow vegetation on the shores of it. In those times the area of the water body was $\sim 62$ ha, volume $\sim 5$ million $\mathrm{m}^{3}$, while the maximal depth reached $23 \mathrm{~m}$. Basic morphometric data about the excavation, according to the state of 2005 , were put in table 3 . Water table was kept on the constant level due to the work of surface pumps removing the excess of water from excavation (15000 $\mathrm{m}^{3} / 24$ hours).

The results of the carried out geotechnical activities in the excavation were comprehensively registered for the first time by geodetic services in 2005, which allowed the definition of basic morphometric parameters of the water body and adjacent areas. The results of this parameterization are presented in table 3, while the cartographic description in the form of a mining map is given in figure 8 .

In case of the surface excavations the main factors guaranteeing the success of water reclamation are (Galiniak G. et al., 2014):

- the necessity of shallowing the excavation;

- shaping the bowl of the water body so that slopes could be stable both above the water and under water;

- the way of filling the excavation with water, providing the conditions for the protection of its quality and stability of scarps. 


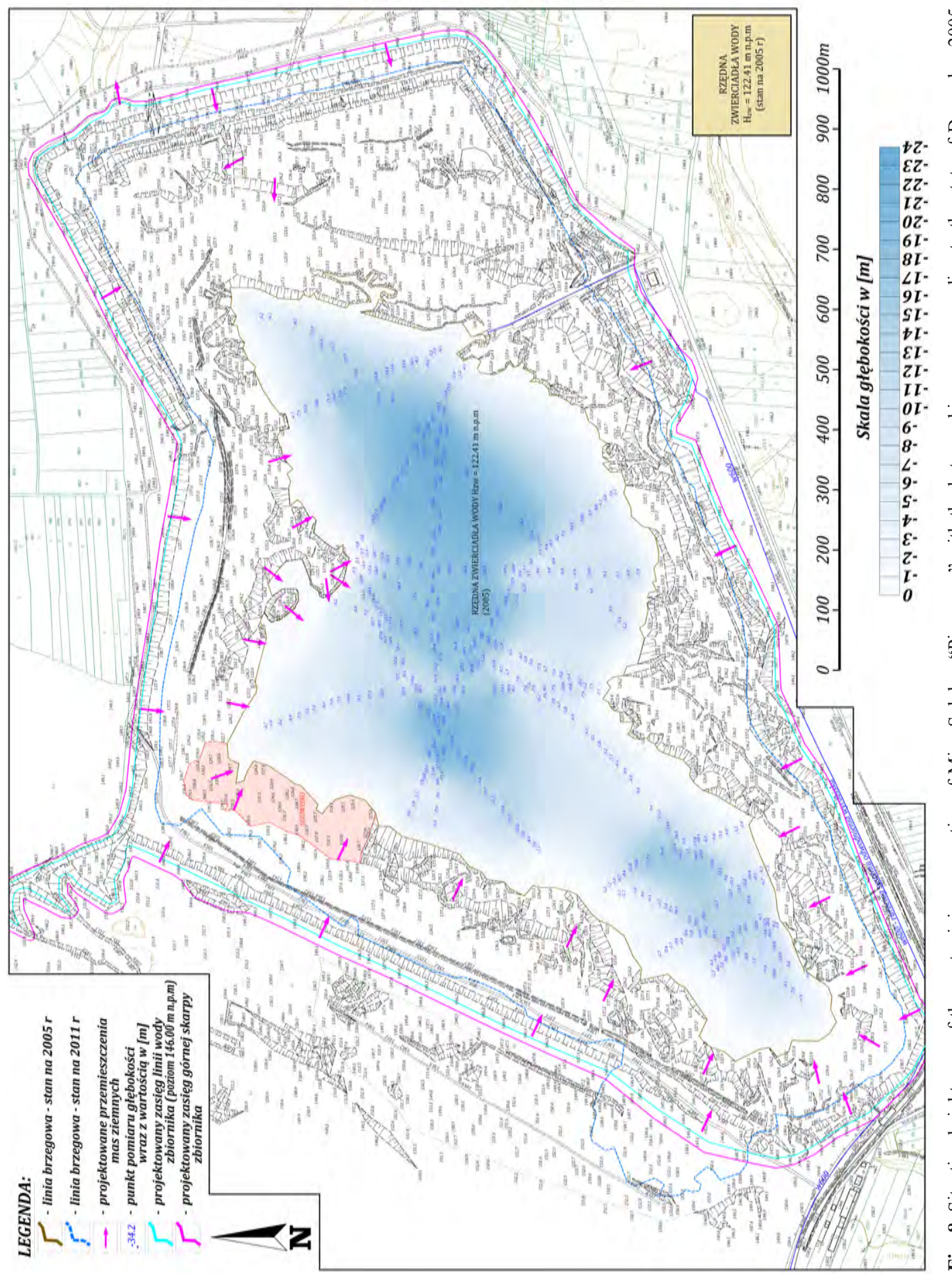


In case of making chemical resources available for mining, safety and keeping high class of water purity, required the isolation of the uncovered chemical series. At the beginning the bottom of excavation was partially filled with water (fig. 8). After the end of mining the Sandomierz sands from its bottom, it was necessary to carry out reclamation works to provide full isolation of the uncovered chemical series preventing poisonous hydrogen sulphide from getting to the surface. Krakowiec clays turned out to be efficient in this aspect and the bottom of the excavation was covered with these clays. Additionally, in the Quaternary formations abrasion surfaces were made to protect the shore from water erosion (Buczek Z. et al., 2010).

To limit the inflow of the waters of the Quaternary and Neogene formations, it was necessary to create a concept of possible options fulfilling this criterion and varying in the degree of efficiency. Among 5 considered ways the one based on full isolation of chemical series scarps with clays, regarding the following aspects:

- ecological (water quality and the content of chlorides and sulphates);

- financial (costs of the implementation of the project);

- technical (possibilities of the enterprise);

- time necessary to carry out the work;

- legal and social.

The isolation materials had to be good quality clays obtained during profiling scarps in the amount of about $800000 \mathrm{~m}^{3}$. To fulfil this condition it was necessary to remove with bulldozers the 1-3 m thick layer of the Quaternary formations covering the clays. In the zone of the deficit of clay masses, motor vehicles were used to supply them (Szmuc M., Madej K., 2010). Profiling and forming new scarps was carried out to the ordinate $+123.0 \mathrm{~m}$ a.s.l. in a safe distance of 1 metre above the water table.

Since 2007, the state enterprise carried out the approved by the Minister of Economy programme of the liquidation of the mining enterprise Sulphur Mine "Machów" S.A. (Program likwidacji zakładów górniczych Kopalni Siarki „Machów” S.A.). It included the liquidation of the mining enterprise in Machów, despite still considerable resources in the deposit. The decision on ending the mining was caused by economic analyses supported by significant decrease of sulphur prices on the world markets and obtaining large quan- tities of sulphur from natural gas and crude oil refining processes.

The programme of the isolation of the layer of chemical series was carried out till the second half of 2009. Then scarps were formed above the ordinate $+137.0 \mathrm{~m}$ a.s.l. on the whole circuit of the water body. Shaping the scarps over water made of sandy and strongly watered grounds in the vicinity of the shoreline indirectly newly shaped the geometry of underwater part of scarps. There were plans to transfer about $300000 \mathrm{~m}^{3}$ of earth masses, which was compliant with the made in 2008 program of the liquidation of the Piaseczno excavation (Program likwidacji wyrobiska Piaseczno). It assumed keeping an already large water body of the area of about 60 ha, being a result of the liquidation of the drainage well in the region of the Machów excavation. With the end of the process of the isolation the scarps of the chemical series, the further stage started. It was connected with damming the waters of the reservoir till the level of +138.0 m a.s.l., which would limit the risk of the inflow of highly mineralized Neocene waters from the eastern direction (Szmuc M., Madej K., 2010) and allowed the liquidation of the pumps pumping the Tertiary waters in the Machów excavation. Also turning off the surface pumps in the Piaseczno excavation was in order to accelerate the process of spontaneous filling the excavation to the given ordinate in the period of 2-3 years. The speed of water damming depended on the intensity of the flow of water to the excavation.

In 2011 the company was communalized and the owner became the Commune of Tarnobrzeg. This was according to the art. $4 \mathrm{~b}$ of the Law on the commercialization and privatization (Ustawa o komercjalizacji i prywatyzacji) of 30 August 1996 (Bąk A., 2015). It was intended that a new, called by the State organ called Sulphur Mine „Machów” had to start works in terms of the liquidation of the results of ending the mining by the state-owned sulphur mines in the areas of the voivodeships of Podkarpacie (deposit Machów) and St. Cross (deposit Piaseczno).

A specific feature of open cast sulphur ore mines and lignite mines in Poland is the formation of areas threatened with mass movements of scarps. Thus it is necessary to carry out geotechnical geological and geodetic monitoring of grounds and buildings located within the range of their occurrence, which allows the limitation of damage and destruction. The integration of interdisciplinary data obtained from new methods 
allows the undertaking of efficient actions to prevent these phenomena. For many years the State Geological Institute (Państwowy Instytut Geologiczny - PIG) has been carrying out a large scale project called System of Anti-Landslide Protection (System Osłony PrzeciwOsuwiskowej - SOPO). The purpose of this is examining the landslides, making maps of the landslide areas and their range, their continuous monitoring and carrying out securing works (Szymczewska P., 2015). Its purpose is (among others) to support governmental and self-governmental administration in effective management of the landslide risk.

A specific form of landslide are mass movements located in:

- mining areas of working mines (lignite mining), in custody of mining enterprises;

- areas liquidated mines (after calling off the mining area) during carrying out the reclamation by the mining enterprise;

- areas of liquidated mines after transferring post-industrial grounds to respective self-government units.

Regardless the characteristic of the threatened area, these phenomena are dangerous to the surface and underground infrastructure, surface of the area and potential users of these areas. In case of Poland (apart from the Carpathian areas) "the Map of Landslides and Areas Threatened with Mass Movements (Mapa osuwisk and terenów zagrożonych ruchami masowymi - MOTZ), and - more precisely - for the Sandomierz District, where post-mining excavation „Piaseczno” belongs is to be implemented in the framework of stage III of the SOPO Projekt planned for 2016 - 2023, after 2022 (http://geoportal.pgi.gov.pl/portal/page/portal/SOPO/ news/pozakarpaty - online 2015). In the framework of the SOPO Projekt it was possible to make an efficient landslide risk management system in the liquidated Sulphur Mine „Piaseczno”, financed so far by the National Fund of Environmental Protection and Water Management (NFOŚiGW), as well as forecasting their possible development, reducing negative effects of these movements and minimisation of possible losses.

Since September 2009 the waters from natural flows have been allowed to fill the excavation at the same time shaping the slopes of the future water body and adjacent areas with the use of heavy equipment has been taking place. The landslide grounds of the overburden are di- rectly adjacent to the spontaneously formed reservoir are highly loose, which contributed to the significant change of physical and mechanical parameters. The most important parameters are endurance features of the grounds, which as a result of digging and transportation to the repository can diminish their endurance even five times. A significant decrease in the mechanic endurance of these grounds is enhanced by the changes in watering in certain conditions result in the loss of stability by the scarps and, consequently, gravitational deformation of the rock mass, i.e. landslide of scarps and slopes of the excavation.

The stability of the slopes of mining excavations is determined by the sum of many factors, such as (Woźniak H., 2009; Rybicki S., Woźniak H., 2010): homogeneity or variability of lithological and facial forming of earth structures, changes of physical and mechanic parameters of the grounds in time, is connected with the impact of withering processes, changes in watering earth masses resulting from the infiltration of the precipitation of waters in the depth of the rock mass and the change in the level of the water table spontaneously formed when the excavation is filled with water.

Unfortunately, the growth of watering of loose ground masses of the inner repository, resulting from lifting the level of the water table (the stage of reconstruction of hydrogeological conditions and accepted water direction of reclamation) and geotechnical activity (translocation of grounds in the shore area with the use of heavy equipment), led to the slide of the fragment of inner repository of $11^{\text {th }}$ May 2011 and small fragment of the repository of glass sands deposed on its top (fig. 9). Apart from the landslide to the water body of the watered ground mass, there were also two excavators falling to the water, including one with the operator. To remember this tragic accident, due to the initiative of the Workers and Managing Board of the Mine "Machów" S.A., over the verge of the western scarp, an obelisk with a cross was erected.

Unfortunately, such phenomena are typical for the scarps of liquidated open-cast mines, especially in case of choosing a water direction of reclamation, when repetitive watering of the ground mass occurs. It is estimated that the range of the phenomenon covers the strap of the terrain equalling $2 \cdot D_{K}\left(D_{K}-\right.$ final depth of the excavation before flooding with water - Dobak P. et al., 2009). 

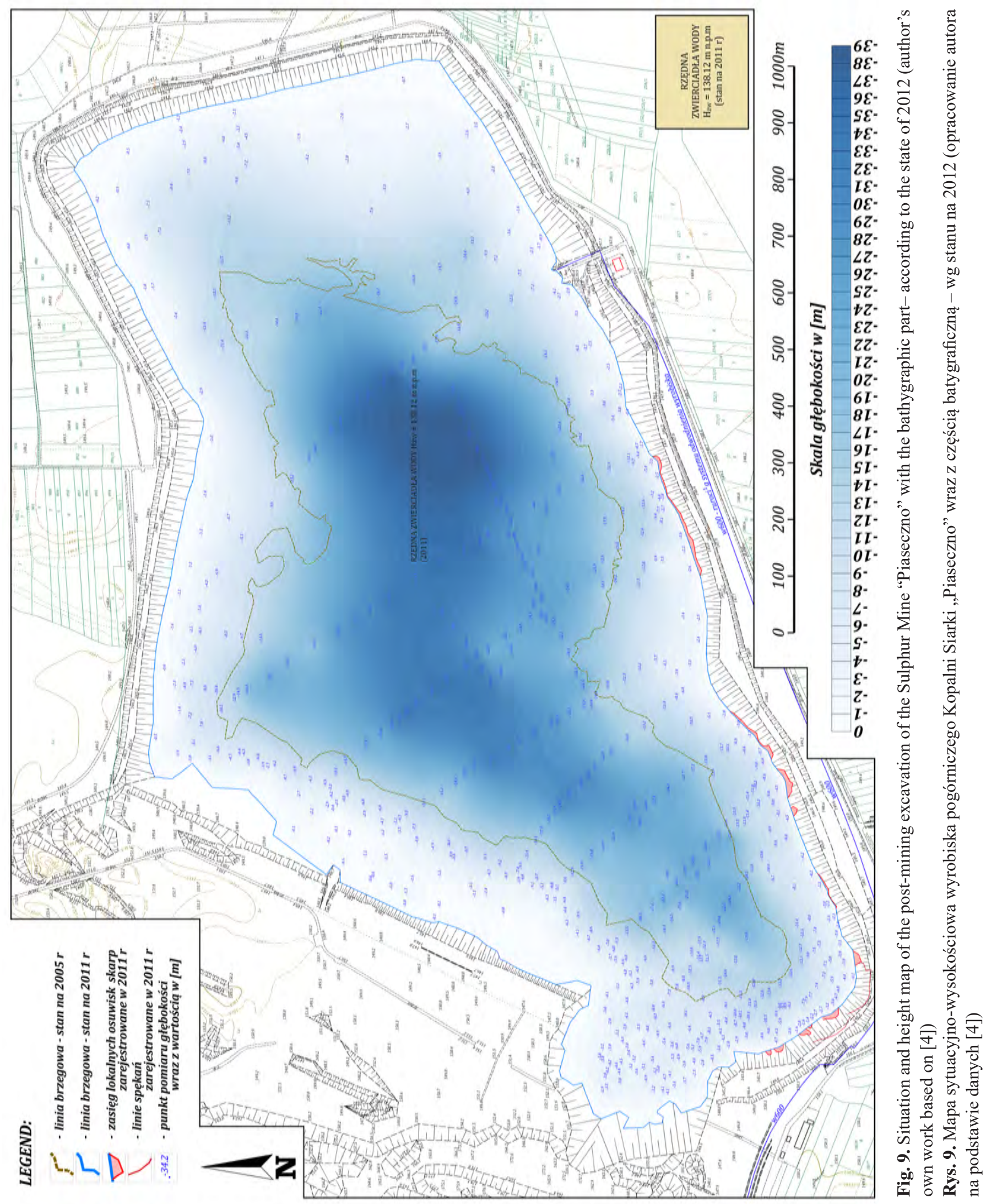
Table 3. Basic morphometric parameters of the excavation and water body Piaseczno, based on the analysis of maps of 2005 and 2012 (by R. Gawałkiewicz based on the data of the Production and Service Enterprise SIGMA BP Ltd. of Tarnobrzeg) Tabela 3. Zestawienie podstawowych parametrów morfometrycznych wyrobiska i zbiornika wodnego Piaseczno, określonych na podstawie analizy map z 2005 i 2012 (opracowanie R. Gawałkiewicz na podstawie danych Przedsiębiorstwa Usługowo-Produkcyjnego SIGMA BP sp. z o.o z Tarnobrzega)

\begin{tabular}{|c|c|c|c|c|c|}
\hline \multirow{2}{*}{\multicolumn{3}{|c|}{ Morphometric Parameter }} & \multirow{3}{*}{$\begin{array}{c}\begin{array}{c}\text { Index of the } \\
\text { parameter }\end{array} \\
\mathrm{X}_{\mathrm{s}} \\
\mathrm{Y}_{\mathrm{s}}\end{array}$} & \multicolumn{2}{|c|}{ Value of the parameter } \\
\hline & & & & \multirow{2}{*}{$\begin{array}{c}\mathbf{2 0 0 5} \\
5601977.46 \\
7542040.55 \\
\end{array}$} & \multirow{2}{*}{$\begin{array}{c}\mathbf{2 0 1 2} \\
5602006.62 \\
7542108.98\end{array}$} \\
\hline \multirow{2}{*}{$\begin{array}{l}\text { Location of the } \\
\text { water body }\end{array}$} & \multicolumn{2}{|c|}{ Geodetic coordinates in system $2000 / \mathrm{PL}$} & & & \\
\hline & & $\begin{array}{l}\mathrm{B} \\
\mathrm{L}\end{array}$ & $\begin{array}{l}50^{\circ} 33^{\prime} 06.95^{\prime \prime} \\
21^{\circ} 35^{\prime} 35.67^{\prime \prime}\end{array}$ & $\begin{array}{l}50^{\circ} 33^{\prime} 07.88^{\prime \prime} \\
21^{\circ} 35^{\prime} 39.15^{\prime \prime}\end{array}$ \\
\hline \multicolumn{3}{|c|}{$\begin{array}{l}\text { Area of the excavation according to Michno W. et al., 2009; } \\
\text { Szmuc M., Madej K., } 2010\end{array}$} & $\mathrm{P}_{\mathrm{wyr}}$ & \multicolumn{2}{|c|}{$\sim 160$ ha } \\
\hline \multicolumn{3}{|c|}{ Volume of excavation according to Michno W. et al., 2009} & $\mathrm{~V}_{\mathrm{wyr}}$ & \multicolumn{2}{|c|}{$\sim 37$ million $\mathrm{m}^{3}$} \\
\hline \multicolumn{3}{|c|}{ Area of the water body } & $\mathrm{P}$ & $\begin{array}{c}607793 \mathrm{~m}^{2} \\
60.78 \mathrm{ha}\end{array}$ & $\begin{array}{c}1398098 \mathrm{~m}^{2} \\
139.81 \mathrm{ha}\end{array}$ \\
\hline \multicolumn{3}{|c|}{ Area of the bottom based on $5 \times 5 \mathrm{~m}$ GRID } & $\mathrm{P}_{\mathrm{dno}}$ & $657406 \mathrm{~m}^{2}$ & $1448571 \mathrm{~m}^{2}$ \\
\hline \multirow{2}{*}{\multicolumn{2}{|c|}{ Volume of the water mass ${ }^{(1)}$}} & $5 \times 5 \mathrm{~m}$ GRID & \multirow{2}{*}{$\mathrm{V}$} & $5565671 \mathrm{~m}^{3}$ & $20196371 \mathrm{~m}^{3}$ \\
\hline & & prismatoids & & $5553832 \mathrm{~m}^{3}$ & $20101576 \mathrm{~m}^{3}$ \\
\hline \multicolumn{3}{|c|}{ Relative error of the water mass volume } & $\mathrm{m}_{\mathrm{V}}$ & $0.21 \%$ & $0.47 \%$ \\
\hline \multicolumn{3}{|c|}{ Ordinate of the water table } & $\mathrm{H}_{\mathrm{zw}}$ & $122.41 \mathrm{~m}$ a.s.1. & $138.12 \mathrm{~m}$ a.s.1. \\
\hline \multicolumn{3}{|c|}{ Minimal ordinate of the bottom } & $\mathrm{H}_{\min }$ & $98.91 \mathrm{~m}$ a.s.1. & $99.62 \mathrm{~m}$ a.s.1. \\
\hline \multicolumn{3}{|c|}{ Maximum depth of the water body } & $\mathrm{G}_{\max }$ & $-23.5 \mathrm{~m}$ & $-38.5 \mathrm{~m}$ \\
\hline \multicolumn{3}{|c|}{$\begin{array}{l}\text { Mean depth of the water body based on } 395 \text { (2005) and } 609 \\
\text { (2012) of bathymetric checkpoints }\end{array}$} & $\mathrm{G}_{\mathrm{sr}}$ & $-11.58 \mathrm{~m}$ & $-11.11 \mathrm{~m}$ \\
\hline \multicolumn{3}{|c|}{ Mean depth of the water body from the formula: $G_{\dot{s} r}=\frac{V_{G R I D}}{P}$} & $\mathrm{G}_{\mathrm{s} r}$ & $-9.16 \mathrm{~m}$ & $-14.44 \mathrm{~m}$ \\
\hline \multicolumn{3}{|c|}{$\begin{array}{c}\text { Mean depth of the water body based on } 38226(2005) \\
\text { and } 56333(2012) \text { of GRID nodes }\end{array}$} & $\mathrm{G}_{\text {sr GRID }}$ & $-9.06 \mathrm{~m}$ & $-14.33 \mathrm{~m}$ \\
\hline \multicolumn{3}{|c|}{ Maximum length $(*)$} & $\mathrm{L}_{\max }$ & $1704.8 \mathrm{~m}$ & $1992.9 \mathrm{~m}$ \\
\hline \multicolumn{3}{|c|}{ Maximum width $(*)$} & $\mathrm{S}_{\max }$ & $608.7 \mathrm{~m}$ & $1052.6 \mathrm{~m}$ \\
\hline \multicolumn{3}{|c|}{ Mean width (based on the length of 40 profiles) } & $\mathrm{S}_{\mathrm{sir}}$ & $397.2 \mathrm{~m}$ & $698.1 \mathrm{~m}$ \\
\hline \multicolumn{3}{|c|}{ Azimuth of the elongation of the water body } & A & $55^{\circ} 19^{\prime}$ & $52^{\circ} 50^{\prime}$ \\
\hline \multicolumn{3}{|c|}{ Shoreline length } & $\mathrm{L}$ & $5377 \mathrm{~m}$ & $5603 \mathrm{~m}$ \\
\hline \multicolumn{3}{|c|}{ Depth index } & W & $0.38\left(^{* 3}\right)$ & $0.37\left(^{* 3}\right)$ \\
\hline \multicolumn{3}{|c|}{ Index of the shoreline development } & $\mathrm{K}$ & 1.95 & 1.34 \\
\hline \multicolumn{3}{|c|}{ Index of the water body elongation } & 1 & 13.5 & 8.0 \\
\hline \multicolumn{4}{|c|}{ Scheme $(*)$} & & \\
\hline
\end{tabular}

(1) - defined in Surfer programme, assuming $5 \times 5$ GRID 
Rapid growth of the ordinate of the water table after the catastrophe and abrasion caused by water waves led to forming abrasion niches alongside the southern and western shore of the water body in the area near the shore, which was documented in the cartographic material of 2012 (fig. 9). Based on the available cartographic materials, morphometric parameterization of the water body according to the state of 2012 was made. A detail list of data and morphometric indexes was put in table 3 .

Initially the finalization of the premises of the program was to take place in 2013. On $1^{\text {st }}$ October 2013 a decision of a total liquidation of the company was made due to the ending of their duties in the framework of the mentioned above Program likwidacji... Bringing the post-mining areas to the functions attributed to the plans of the reclamation called "Reclamation of post-mining areas of the Sulphur Mine "Machów" S.A. in the areas "Machów-Piaseczno", "Jeziorko”, "Basznia” (,Rekultywacja terenów pogórniczych Kopalni Siarki „Machów” S.A. w obszarach: „Machów-Piaseczno”, , Jeziorko”, „Basznia”) - stage 2011-2015 is nowadays financed from the donation
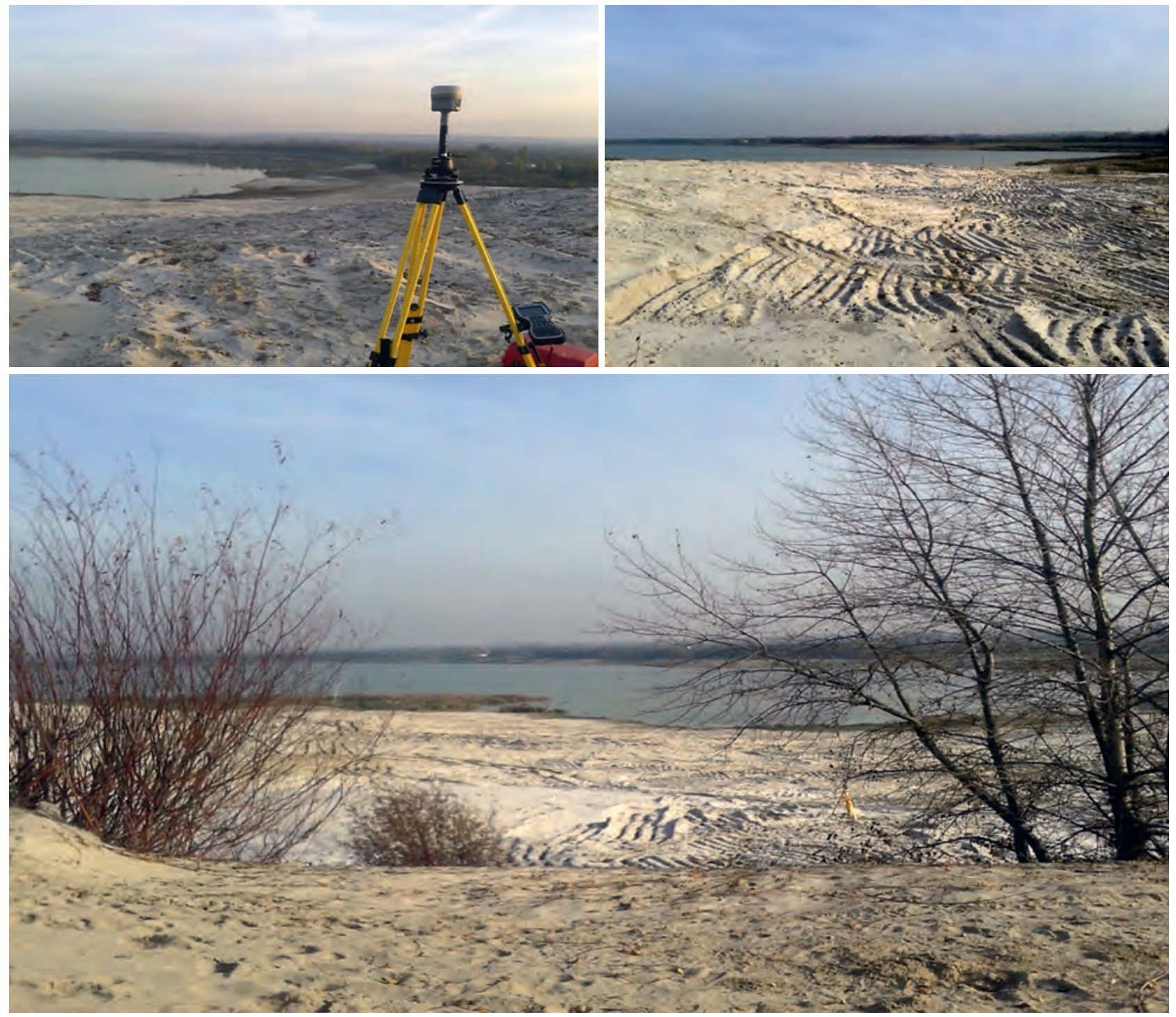

Fig. 10. Culmination of the repository of glass sands - in the background - indentation in the shoreline after the landslide in 2011 (state: November 2015)

Rys. 10. Kulminacja składowiska piasków szklarskich - w tle wyłom w linii brzegowej po osuwisku w 2011 (stan: listopad 2015) 
of the National Fund of Environmental Protection and Water Management (NFOŚiGW) based on the Law of financial restructuring of sulphur mining (Ustawa o restrukturyzacji finansowej górnictwa siarki) of $14^{\text {th }}$ July 2000 (Dz.U. z 2003, no. 176, position 1693).

Due to various causes (e.g. the landslide in 2011 in the north-west part) the deadline for ending of works was postponed several times - the end of 2015, and then 2016. Despite postponing the deadlines the plan has not been fulfilled.

Carried out for years mining in Piaseczno and Machów led to immense degradation of environment in the following (Bąk A., 2015):

- distorting water balance (formation of a huge depression funnel, causing the drainage of many thousands of hectares of the land);

- soil acidification;

- destruction of flora and fauna;

- activation of landslide, including the most tragic on of $11^{\text {th }}$ May 2011 in north-west part of the „Piaseczno" excavation (fig. 10).

\section{CLOSING REMARKS}

The post-mining excavation Piaseczno has not been transformed into a safe water body yet. Despite substantial experience of the Polish mining in effective liquidation of large lignite excavations (Pątnów, Przykona, Kazimierz Południe), sulphur excavation (Machów), sand and gravel excavations (Dzierżno Duże, Pogoria IV, Pławinowice) in Piaseczno despite 15 years of the liquidation the efforts to complete reclamation have not succeeded yet.

Although nowadays it is an inaccessible and dangerous area (reclamation process is in progress), already today, with the surrounding area makes an interesting element of local landscape and it is an attractive area from the ecological point of view. Planned flooding of the excavation to the level of $+146 \mathrm{~m}$ a.s.l. and providing the stability of its scarps, will still require many geotechnical measures (reshaping of scarp geometry, using modern techniques in the process of their securing) and making the watering and drainage system of the adjacent areas, which from the beginning of mining works of the deposit were drained and converted from wetlands into orchards and buildings (fruit and agricultural enterprising). The prolongation of the time of flooding excavations negatively influences a stability of the slopes and the bowl of the lake. Elevating the level of the water table contributes to unfavourable and uncontrolled changing of the profile slopes, which was documented in the $2^{\text {nd }}$ part of this paper.

The analysis of the available archival cartographic and descriptive materials allowed us to get familiar with the history of the closed mine and illustrate the characteristics of the changes of excavations from the end of mining Baranów sands in 1980 until 2012 (latest comprehensive inventory of the excavation). The amount of information contained in the analysed materials, allowed us to define the impact of mining and the range of natural phenomena (mass movements), which shaped the excavations until 2012. Introduced morphometric parameters of the bowl of the water body and the part of the excavation above the water in subsequent states of registration give the picture of carried out so far activities and make a valuable comparative material for subsequent periods of time and stages of reclamation, which was included in the second part of the article, covering the period of 2012-2020.

\section{REFERENCES}

Bąk A., (2015): Apel Sejmiku Województwa Świętokrzyskiego do Marszałka Sejmu Rzeczpospolitej Polskiej o wprowadzenie pod obrany Sejmu RP ustawy o zmianie ustawy z dnia 30 sierpnia 2013 roku o dotacji dla niektórych podmiotów. (Dz.U. z 2013r, poz. 1160).

Bocheńska T., Kleczkowski T., Różkowski A.S., (1997): Słownik hydrogeologiczny. Ministerstwo Ochrony Środowiska, Zasobów Naturalnych i Leśnictwa. Wydawnictwo Trio, Warszawa, p. 327

Buczek Z., Szmuc M., Madej K., (2010): Budowa zbiornika wodnego $w$ wyrobisku poeksploatacyjnym byłej Kopalni Siarki Piaseczno. Górnictwo i Geoinżynieria. Vol. 34, issue 4, p. 101-106.

Ciupa T., Suligowski R., (2018): Hydrologiczne aspekty funkcjonowania planowanego zbiornika wodnego , Wierna Rzeka” (Wyżyna Przedborska). Woda-Środowisko-Obszary Wiejskie. Vol. 18, issue 1 (61), p. 5-22.

Czajkowski R., Czuryło Z., Michno W., (2012): Zagrożenia środowiska spowodowane uszkodzeniem konstrukcji otworu wiertniczego. Materiały Sympozjum - Warsztaty 2012 z cyklu: Zagrożenia naturalne w górnictwie, p. 41-55.

Dobak P., Drągowski A., Frankowski Z., Frolik A., Kaczyński R., Kotyrba A., Pinińska J., Rybicki S., Woźniak H., (2009): Zasady dokumentowania warunków geologiczno-inżynierskich dla celów likwidacji kopalń. Warszawa.

Flisiak J., Frankowski Z., Haładus A., Majer E., Kowalski M., Pietrzykowski P., Rybicki S., (2014): Rozwój i określenie przyczyn osuwiska na skarpie zbiornika wodnego po odkryw- 
kowej kopalni siarki „Piaseczno”. Przegląd Geologiczny. vol. 62, no. 4, p. 190-215.

Galiniak G., Polak K., Różkowski K., Kaznowska-Opala K., Pawlecka K., (2014): Rekultywacja wodna jako czynnik determinujący sukces branży górnictwa odkrywkowego w praktyce sozologicznej. Przegląd Górniczy, no. 10, p. 122-127.

Goszcz A., (2001): Możliwości i ograniczenia w przywracaniu użyteczności terenom górniczym. Warsztaty 2001 nt. „Przywracanie wartości użytkowych terenom górniczym”. Sympozja i konferencje - Polska Akademia Nauk - Instytut Gospodarki Surowcami Mineralnymi i Energią, no. 49, p. $95-108$.

Gutman E., Kwiecień K., (1982): Przemyst siarkowy w Polsce. KAW, Rzeszów.

Gutman E., Kwiecień K., (1992): Polska siarka. Zakład Wydawniczo-Usługowy Adam Konieczny. Warszawa.

Kubica B., Osmólski T., (1964): Notatki z historii kopalnictwa siarkowego w Polsce. Instytut Geologiczny. UKD 622. 366.1(438)"1402/196, p. 260-262.

Kwiecień K., (1978): Polska siarka. KAW, Kraków.

Michno W., Dziedzic W., Czajkowski R., (2009): Przywracanie wartości użytkowych terenom górniczym na przykładzie KiZPS ,, Siarkopol”. Materiały Sympozjum - Warsztaty 2009 z cyklu: Zagrożenia naturalne w górnictwie, p. 197-211.

Mitura T., (2015): Zagospodarowanie terenów pogórniczych na potrzeby turystyki i rekreacji na przykładzie Jeziora Tarnobrzeskiego. Rozprawy Naukowe Akademii Wychowania Fizycznego we Wrocławiu, issue 50, p. 49-58.

NAJWYŻSZA IZBA KONTROLI (2018): Rekultywacja i zagospodarowanie terenów pogórniczych byłego wyrobiska Piaseczno Kopalni Siarki Machów S.A. w likwidacji . Informacja o wynikach kontroli.

Nieć M., (1970): Morfologia stropu złóż siarki i jej wpływ na mikrotektonikę skat nadkładu. Rocznik Polskiego Towarzystwa Geologicznego, vol. XL, issue 2, Kraków, p. 325-341.

Pargieła J., (2018): Rekultywacja i zagospodarowanie gruntów przekształconych $w$ wyniku odkrywkowej eksploatacji kopalin na podstawie koncesji udzielonej przez starostę. Warsztaty - Aspekty administracyjno-prawne i środowiskowo-społeczne odkrywkowej eksploatacji kopalin. 3-4 październik 2018 r. Bogatynia, p. 123-132.

Pawłowski S., (1956): Dokumentacja geologiczna złoża siarki w Piasecznie koło Koprzywnicy. Narodowe Archiwum Geologiczne, no. 4633/181, Warszawa.

Pawłowski S., Pawłowska K., Kubica B., (1965): Kopalnia siarki w Piasecznie. Instytut Geologiczny. Warszawa, p. 252-257.

Pawłowski S., (1983): O historii odkrycia złóż siarki rodzimej $w$ Polsce (1952-1982). Kwartalnik Historii Nauki i Techniki 28/2, p. 405-424.

Percovich M.G., Markovich L.P., (1966): Про прогнози зсувів на бортах кареру роздольского родовища сірки. ДАН УPCP. 1.

Rybicki S., (1986): Structure and physico-mechanical properties ofdump soils. [W:] Proceedings of the $5^{\text {th }}$ International IAEG Congress, Buenos Aires. Balkema, Rotterdam-Boston, p. 1019-1027.
Rybicki S., Woźniak H., (2010): Struktura i geotechniczne właściwości wybranych gruntów antropogenicznych. Przegląd Geologiczny, no. 58, p. 926-932.

Sokołowski J., Socha M., Felter A., (2016): Studium możliwości występowania $i$ wykorzystania wód leczniczych i termalnych w Tarnobrzegu wraz z określeniem uwarunkowań formalno-prawnych poszukiwania i eksploatacji wód oraz możliwości finansowania podziemnej czesści inwestycji (otworu wiertniczego). Państwowy Instytut Geologiczny - Państwowy Instytut Badawczy, Warszawa.

Staszewski R., (2014): Ta bomba może wybuchnać. Tygodnik Nadwiślański z dnia 4 marca 2015.

Sybilski D., Kraszewski C., Duszyński A., Wileński P., Pachowski J., Mirski K., (2004): „Ocena i badania wybranych odpadów przemysłowych do wykorzystania w konstrukcjach drogowych". Instytut Badawczy Dróg i Mostów w Warszawie, Warszawa.

Szczepiński J., (2018): Wplyw odkrywkowej eksploatacji kopalin na środowisko. Warsztaty - Aspekty administracyjno-prawne i środowiskowo-społeczne odkrywkowej eksploatacji kopalin. 3-4 październik 2018 r. Bogatynia, p. 43-54.

Szmuc M., Madej K., (2010): Likwidacja wyrobiska „Piaseczno" - budowa zbiornika wodnego. Górnictwo i Geologia, vol. 5, issue 2, Wydawnictwo Politechniki Śląskiej, Gliwice.

Szmuc M., Madej K., (2011): Była siarka! Co jest teraz?. Górnictwo i Geologia, vol. 6, issue 1, Wydawnictwo Politechniki Śląskiej, Gliwice.

Szymczewska P., (2015): Groźne osuwiska: jak ograniczyć zniszczenia. Dziennik Polski no. 116 (21557) of 20 ${ }^{\text {th }}$ May 2015, Kraków.

Woźniak H., (2009): Właściwości deformacyjne i filtracyjne zwałowanych gruntów spoistych z wybranych kopalń odkrywkowych $w$ aspekcie ich budowlanego wykorzystania. Wydział Geologii, Geofizyki i Ochrony Środowiska. AGH Kraków, p. 1-114.

\section{UNPUBLISHED MATERIALS}

[1] Dodatek nr 1 do Planu Ruchu Kopalni Machów - Piaseczno na lata 1974-1975, część II - Eksploatacja piasków baranowskich dla celów Przemysłu Szklarskiego, Kopalnie i Zakłady Przetwórcze Siarki „Siarkopol” w Machowie.

[2] Sandomierskie Stowarzyszenie Rozwoju Regionalnego Lokalna Grupa Działania, Sandomierz 2007.

[3] „Dokumentacja geologiczno-inżynierska dla zabezpieczenia skarp projektowanego składowiska PIASECZNO oraz wykonania projektu technicznego obiektów w obrębie wyrobiska PIASECZNO”, Przedsiębiorstwo Geologiczne w Krakowie, Kraków 1987.

[4] Projekt techniczny prac zabezpieczających i rekultywacji wyrobiska byłej Kopalni Siarki Piaseczno - Uporządkowanie, profilowanie skarp wyrobiska i izolacja wychodni serii chemicznej - grudzień 2005 - Przedsiębiorstwo Usługowo-Produkcyjne SIGMA BP Sp. z o.o. w Tarnobrzegu. 